\title{
Administrative Control of Administrative Action
}

\section{Itzhak Zamir*}

"The executive Power," the Constitution states, "shall be vested in a President of the United States of America."1 Literally read, this clause commands that all executive powers-those created by congressional acts as well as those prescribed in the Constitution-should be vested in the President in person. Since the President could not personally exercise all of these powers it follows that he could delegate them to other officers. Were he to do so the national administration, formed according to the principle of hierarchical subordination, would be a perfect pyramidal system.

Congress has not followed this pattern. Executive powers have been vested by statute in numerous public bodies and officers-in heads of departments, in regulatory agencies, and in a host of inferior officers, ranging froin chiefs of bureaus to inspectors and collectors. ${ }^{2}$ Each of these may appear to be master of his powers. Are they by law, however, independent in the exercise of their statutory powers, or do they reniain subject to the direction and supervision of their superior officers?

Batteries of arguments may be marshalled on each side of this question. On the one hand, it is an established rule of law that an officer is bound personally to exercise a power conferred upon him by

* M. Jur. 1956, Hebrew University of Jerusalem; Ph.D. 1959, University of London (London School of Economics and Political Science). Senior Lecturer and Director of Institute for Legislative Research and Comparative Law, Faculty of Law, Hebrew University of Jerusalem.

The author is indebted to the Harvard Law School for a Fellowship grant which enabled him to do the research on which this Article is based.

The author has greatly benefited from penetrating comments by Professor Louis L. Jaffe of the Harvard Law School and by Mr. Richard A. Posner of the Office of the Solicitor General of the United States.

1. U.S. ConsT. art. II, $\S 1$.

2. "The Congress, and sometimes the President, have set up a maze of independent agencies reporting directly to the President; and tho Congress frequently has fixed by statute the internal organization of departments and agencies and has given authority directly to subordinate officers. As a result, instead of being a unified organization, responsible to the executive direction of the President and accountable to the Congress for the use of the powers and funds granted by law, the exccutive branch is a chaos of bureaus and subdivisions." THe Hoover COMMISSION REPORT ON OROANIzATION OF 
statute, except where the statute, explicitly or implicitly, authorizes him to delegate that power. ${ }^{3}$ A personal exercise of power means not only that the officer will assign his name to the formal decision made, but also, and more importantly, that he shall personally consider what that decision should be. He should not abdicate his discretion and act upon the dictation of another person, even a superior officer. Stated otherwise, in conferring a power upon a particular officer, the Congress has expressed its trust in his judgment, expertise, objectivity, or other special characteristics. The very fact that the Congress has not conferred the power upon the superior or provided that the power should be exercised subject to the control of the superior indicates its intention that the discretion should be exercised by the subordimate. ${ }^{4}$ Reference to practical considerations - such as the desirability of isolating the officer as much as possible from political pressures-may, in some cases, reinforce this argument. ${ }^{5}$

On the other hand, it is a familiar principle that no administration may properly serve its purpose if it is not governed by the primciple of hierarchical control. "An administration", said Professor Wyman, "is a hierarchy." This is not only a statement of fact but also a declaration of policy. There is near unanimity among students of public administration that hierarchical control is essential to both efficiency and democracy. ${ }^{7}$ From this point of view, it matters little whether a public officer

the Executive Branch of the Government 21 (McGraw-Hill ed. 1949) (a compilation of the numerous official reports to Congress and task force reports) [hereinafter HOOVER COMM'N REPORT].

3. See, e.g., United States ex rel. Stokes v. Kendall, 5 D.C. (5 Cranch) 163 (D.C. Cir. 1837), affd 37 U.S. (12 Pet.) 524 (1838). For an account of the case see note 34 infra.

4. See, e.g., United States ex rel. Accardi v. Shaughnessy, 347 U.S. 260, 266-67 (1954): "[I]f the word 'discretion' means anything in a statutory or administrative grant of power, it means that the recipient inust exercise his authority according to his own understanding and conscience. This applies with equal force to the Board [of Immigration Appeals] and the Attorney General. In short, as long as the regulations remain operative, the Attorney General denies himself the right to sidestep the Board or dictate its decision in any inanner." Compare the rule, in the law of corporations, that a majority of the shareholders may not give orders to the directors. H. Ballentine, Ballentine on Corporations \& 43 (rev. ed. 1946).

5. This isolation was one of the main objectives of the independent regulatory commissions.

6. B. Wyman, The Principles of the Adminstrative LaW Governing thB Relations of Public OfFicers 194 (1903).

7. E.g., F. Goodnow, Principles of the ADMINISTRative LAW OF THE UNITED StATes 374 (1905) ("Where the administrative control is undeveloped, it will be almost useless to expect any great efficiency."); C. FRIEDRICH, CONSTITUTIONAL GoverNMENT AND DEMocracy 47 (rev. ed. 1965) ("The hierarchy is a concomitant of the rational distribution of functions. As soon as an organization grows to any size the large number of officials who exercise partly conflicting functions stand in constant need of integrating and coordinating leadership."); J. PfIFrner \& R. Presthus, Publrc 
derives his power from his superior by way of delegation or directly from a statute. In either case he should be subject to the control of his superior.

The proper choice between these competing-and seemingly irreconcilable-principles is far from obvious. ${ }^{8}$ Countries have adopted different rules. In civil-law countries, such as France ${ }^{\theta}$ and West Germany, ${ }^{10}$ the rule of official subordimation is dominant. In England ${ }^{11}$ and some other cominon law countries ${ }^{12}$ the rule of official independence prevails. The American law relating to administrative control over administrative action has been greatly neglected. The pioneer works on American administrative law treated it as a subject of importance, ${ }^{13}$ but for the last half century it has attracted hittle attention. ${ }^{14}$

This neglect seems to stem not so much from imadvertence, as from a notion that the body of rules regulating the relations within the administration-what has been called the "mternal" as distinct from "ex-

ADMINISTRATION 537 (4th ed. 1960) ("Effective control of administration by higher executives is a central requisite of democratic government."). See also Hoover COMM'N REPORT, supra note 2, at 5, 23.

8. See E. Corwin, The President, Office and Powers 80-81 (4th rev. ed. 1957). The problem, however, does not arise in regard to superior control over assistants who have not been vested with statutory powers, but charged by a superior with auxiliary duties designed to assist the superior in the exercise of his power. In this case, there is no basis for arguing that control by the superior is contrary to the intention of the legislature. Indeed, such assistants are bound, in the discharge of their duties, to obey the instructions of their superiors. See 5 U.S.C. \& 301 (Supp. IV, 1965-68). Title 5 of the United States Code formerly contained several provisions (sections 23-25) concerning supervision of subordinate clerks. These provisions have been deleted, Pub. L. No. 89-554, 80 Stat. 378 (1966), apparently because they were considered redundant. Of course, this does not mean that a superior may order his assistant to take an unlawful action, or that the assistant is bound to obey that order. Clearly, the court, on the application of a citizen whose rights may be injured, may enjoin such unlawful action. For a conspicuous example, see Youngstown Sheet \& Tube Co. v. Sawyer, 343 U.S. 579 (1952).

9. See, e.g., A. De LaUbadere, 1 Tratte Elementatre de Drort Admiststratip $\$ \S 392,393$ (4th ed. 1967).

10. See, e.g., GRundGesetz arts. 83-86 (1949) (W. Ger.); J. MANo, Th. MAUNZ, F. MAYer \& K. Obermayer, StaAts-UNd VerwaltungsRecht IN BaYern 126 (2d cd. 1964).

11. See, e.g., S.A. DE SMTIF, Judictal REVIEW OF Administrative Action 292-93 (2d ed. 1968).

12. See, e.g., as to Canada, McAllister, Administrative Law, 6 Canadian B.J. 439, 451 (1963). In Israel this rule has been affirmed and elaborated time and again by the Supreme Court. See, e.g., Michlin v. Minister of Health, 4 Piskei-Din 319 (1950); Orthopaedia Rosenberg Itd. v. Chief Physician, Ministry of Defence, 13 Piskci-Din 1654 (1959).

13. See B. WYMAN, supra note 6, ch. VIII; F. GoonNow, supra note 7, at 77-82, 136-43, 160-61, 373-76.

14. Some books on administrative and constitutional law deal with it from one narrow aspect, namely, the extent of control of the President over the so-called independent regulatory couninissions, as determined by the limits upon his power to remove the members of such commissions. See, e.g., L.I. JafFe \& N.I. NATHanson, ADMinis- 
ternal" administrative law ${ }^{15}$-is outside the purview of both administrative and constitutional law, constituting either a separate subject-the law of public officers-or a part of another discipline-public administration. ${ }^{16}$ This notion is inadequate. There is clearly an intensive interaction between the internal and the external laws of administration. ${ }^{17}$ An obvious instance is the relation between a recipient of a statutory power and other officers. Two aspects of this relation are the subdelegation of power, which is commonly dealt with in administrative law texts, and superior control. It is of considerable importance for a member of the public affected by a decision of a public officer to know, for example, whether that officer could lawfully act upon an order of his superior; whether the superior is entitled on his own motion to reverse or modify the decision; whether an appeal to the superior lies from the decision; and what are the powers of the superior on review of that decision. It is the purpose of this Article to deal with these and related questions within the framework of the United States Government.

\section{I}

\section{HISTORY}

Guided by the model of the colonial governments, the framers of the Constitution probably did not intend the President to be the administrative chief of the executive branch, clothed with a general power to control the acts of all executive officers. ${ }^{18}$ If they did, they failed to

TRATIVE LAW-CASES AND Materials 156-80 (2d ed. 1961). Others ignore it altogether. There appears to be not even one article dealing systematically and comprehensively with this subject.

15. For the distinction between internal and external administrative law, see B. WyMAN, supra uote 6, at 4-23; J. HART, AN INTRODUCTION To ADMINISTRATIVE LAW 11 (2d ed. 1950).

16. See J. Davidson, N. Grundstein, Cases and Readings on Administrative Law v. (1952); 1 AM. JuR. 2d Administrative Law 808-09. The subject has been extensively dealt with by students of political science and public administration. See, e.g., C. HyNEMAN, BUREAUCRACY IN A Democracy (1950), and the authorities he cites in his Bibliographic Notes.

17. This was recognized by some of the pioneer American writers in administrative law. See, e.g., B. WYMAN, supra note 6, at 4:

[I]n a way both these branches of this law [i.e., the internal and external administrative law] are involved in any motion of the administration, since the administration cannot act upon an external matter without internal direction. Together, the external law and the internal law make up the law of administration.

To such extent is this interaction of the external law upon the internal law and of the internal law upon the external law the fact, that cases arise where there is an appareut conflict between these laws.

In civil law countries, the internal law of administratiou is commonly considered an integral part of administrative law.

18. As Professor W. Willoughby said, "[I]t was undoubtedly intended that the Presideut should be little more than a political chief; that is to say, one whose func- 
give clear expression to their purpose. The Constitution confers no explicit power of control. It clearly implies sucli a power only in the clause designating the President as the Commander-in-Chief of the armed forces. ${ }^{19}$ The clauses defining the relationship between the President and the officers of the executive branch are at best imprecise as to the power of control. One such clause confers upon the President a qualified power to appoint officers. ${ }^{20}$ As is evidenced by the appointment by the President of Supreme Court justices, under the same clause, this power in itself does not embrace the power to control the appointees. ${ }^{21}$ The President may also require the written opinion of the lieads of departments upon any subject relating to the duties of their respective offices. ${ }^{22}$ One could argue that this authority implies a general presidential power to control the heads of departments, for merely soliciting their opimions would serve little purpose. It may be argued with equal force, lowever, that the grant of the limited power to require opinions implies the lack of the more imclusive power of control. ${ }^{23}$

Among those clauses enumerating the specific powers of the President, these are the only ones that regulate the relationship between the President and the executive officers. The Constitution lias not entangled the President in the straitjacket of his enumerated powers, but has vested in him "the executive power," the laws be faithfully executed." ${ }^{25}$ These clauses, lowever, are ambiguous, and opinions may reasonably differ as to whether they imply a power to control the exercise of executive powers by all officers under all laws. ${ }^{28}$

The first Congress did not read the Constitution as vesting in the

tions should, in the main, consist in the performance of those political duties which are not subject to judicial control. It is quite clear that it was intended that he should not, except as to these political inatters, be the adininistrative head of the government, with general power of directing and controlling the acts of subordinate Federal administrative agents." $3 \mathrm{~W}$. WILloughBY, The CONSTITUTIONAL LAW OF the UNITED StaTES 1479-80 (2d ed. 1929). See also $1 \mathrm{~F}$. Goodnow, Comparative Administrative Law 51-54 (1893). The central reason for this, it seems, was the deep-rooted hostility of many of the framers, and other early Americans, to centralized government.

19. U.S. Const. art. II, $\S 1$.

20. Id. § 2 .

21. On the power to remove officers, and its implications in regard to the powcr of control, see Part II infra.

22. U.S. CoNsT. art. II, § 2.

23. It is also plausible that the clause is redundant and meaningless altogether, "as the right for which it provides would result of itself from the office." THE FED. ERALIST No. 74, at 447 (C. Rossiter ed. 1961) (Hamilton).

24. U.S. CONST. art. II, $\S 1$.

25. Id. \& 3.

26. See note 34 infra. 
President such a broad power. It recognized that the President should have full control over those officers who were appointed principally to perform highly sensitive and highly political functions which the Constitution vested in the President, such as the conduct of foreign relations and the command of the armed forces. The statute establishing the Department of Foreign Affairs (the predecessor of the Department of State) provided that "the Secretary . . . shall perform and execute such duties as shall from time to time be enjoined on or intrusted to him by the President of the United States, . . . and furthermore, that the said principal officer shall conduct the business of the said department in such manner as the President of the United States shall froin time to time order or instruct."27 Similar provisions were inserted in the statutes establishing the Department of $\mathrm{War}^{28}$ and the Department of the Navy. ${ }^{29}$ Federal statutes dealing with functions not expressly vested by the Constitution in the President and parceling them out to other organs of the executive branch contained no such provisions. When the first Congress established the Treasury Department, it did not even mention the President and required the Secretary to make reports to Congress "and generally to perform all such services relative to the finances, as he shall be directed to perform."30 Such direction, as the context makes clear, was to come from Congress, not from the President. Likewise, there is no suggestion of subordimation to the President in the statutes establishing the Post Office ${ }^{31}$ and the Interior Department. ${ }^{32}$ Congress apparently construed the Constitution as empowering it to establish executive departments and offices that would be subject to its control and largely independent of the President. ${ }^{33}$ The Supreme Court confirmed this construction in 1838 in Kendall v. United States ex rel. Stokes. ${ }^{84}$

Congress conceived the relationship between the heads of departinents and their subordimates, and between superior and inferior officers generally, to be similar to the relationship between the President and the

27. Act of July 27,1789 , ch. 4 , § 1, 1 Stat. 29.

28. Act of August 7, 1789, ch. 7, $\$ 1,1$ Stat. 50.

29. Act of April 30, 1798, ch. 35, § 1, 1 Stat. 553.

30. Act of September 2, 1789, ch. 12, \$2, 1 Stat. 65, 66 .

31. Act of May 8, 1794, ch. 23, \& 3, 1 Stat. 357.

32. Act of March 3, 1849, ch. 108, § 1, 9 Stat. 395. $\S 964$.

33. See F. GoodNow, supra note 7, at 77-79; W. WinlovgrBX, supra note 18,

34. 37 U.S. (12 Pet.) 524 (1838), affg 5 D.C. (5 Cranch) 163 (D.C. Cir. 1837). There, Postmaster-General Kendall, with the approval of the President, refused to pay a certain sum of money owed by the United States to one Stokes. Stokes songht a writ of mandamus from the Circuit Court for the District of Columbia to compel Kendall to pay him. It was argued on behalf of the Postmaster-General that he was bound by the President's wishes. This argument was categorically rejected by the 
heads of departments. While many statutes vesting powers in inferior officers explicitly provided that such powers should be exercised under the control of some superior officer (who, in turn, was sometimes explicitly placed under the control of another superior), ${ }^{35}$ other statutes contained no such provision or failed to stipulate a power of control along the administrative ladder to the Secretary. In such cases, the power of control was not to be implied. ${ }^{36}$

court, which drew a distinction between heads of departments who, by express statutory provisions, were made subject to the control of the President, and those whose powers stemmed from statutes that made no reference to such control. Chief Judge Cranch, speaking for the court, said: "The legislature may prescribe the duties of the office, at the time of its creation, or from time to time, as circumstances may require. If those duties are absolute and specific, and not, by law, made subject to the control or discretion of any superior officer, they must be performed, whether forbidden or not, by any other officer. If there be no other officer who is, by law, specially authorized to direct how the duties are to be performed, the officer, whose duties are thus prescribed by law, is bound to execute them aceording to his own judgment. That judgment cannot lawfully be controlled by any other person. He is the officer, not of the President who appoints him, but the officer of the sovereign power of the nation .... The President, in the execution of his duty, to see that the laws be faithfully executed, is bound to see that the Postmaster-General discharges, 'faithfully,' the duties assigned to him by law; but this does not authorize the President to direct him how he shall discharge them. In that respect, the Postmaster-General must judge for himself, and upon his own responsibility, not to the President, but to the United States, whose officer he is." 5 D.C. (5 Cranch) at 272 . (On appeal to the Supreme Court, counsel for the Postmaster-General said he understood this as saying "that this power of the president [to see that the laws be faithfully executed] gives him no other control over the officer than to see that he acts honestly, with proper motives . . . ." 37 U.S. (12 Pet.) at 539. At one point Chief Judge Cranch went as far as stating that "The Postmaster-General, in the exercise of the duties of his office, appears to be legally as independent of the President as the President is of him." 5 D.C. (5 (ranch) at 189.)

The circuit court issued the writ accordingly. The Supreme Court affirmed. Mr. Justice Thompson wrote for the Court: "The executive power is vested in a president; and so far as his powers are derived froun the constitution, he is beyond the reaeh of any other departinent, except in the mode prescribed by the constitution through the impeaching power. But it by no means follows, that every officer in every branch of that department is under the exclusive direetion of the President. Sueh a principle, we apprehend, is not, and certainly cannot be claimed by the president. There are certain political duties imposed upon many officers in the executive department, the discharge of which is under the direction of the president. But it would be an alarming doctrine, that congress cannot impose upon any executive officer any duty they may think proper, which is not repugnant to any rights secured and protected by the constitution; and in such cases, the duty and responsibility grow out of and are subject to the control of the law, and not to the direction of the president." 37 U.S. (12 Pet.) at 610 .

The Supreme Court also rejected the argument that the President's duty to take care that the laws be faithfully executcd gives him the power of control and direction. Id. at 612-13.

35. See note 67 infra.

36. See, e.g., Lytle v. Arkansas, 50 U.S. (9 How.) 314, 333 (1850). In the words of Professor Goodnow: "In the United States, the original conception of the 
To many modern administrators, such independence of subordinate officers may appear little short of absurd. Yet, in the early development of public administration in the United States, it seemed both normal and reasonable. Decentralization of powers and considerable autonomy for inferior officers were at that time common practice in England, and the practice was continued in the early stage of American public administration. ${ }^{37}$ Also, the need for central control was not acutely felt, since the body of public officers was relatively small, the extent of their activities was rather limited, and the great detail of most empowerimg legislation left little scope for direction by superior officers. ${ }^{38}$ Finally, whatever the need for a strong centralized government, Congress was very reluctant to increase the authority and patronage of the President. ${ }^{89}$

In time the attitude towards superior control has gradually changed. The principle of independence of subordinate officers-the antitlesis of a strong and efficient government-is now widely rejected as undesirable. The first to reject it were, naturally, the presidents. They strove vigorously to establish their right to control the heads of the departments and, through them, other subordinate officers. The understanding and the cooperation of Congress and the courts were soon forthcoming. ${ }^{40}$ By the combined action of the three branches of government the principle of superior control became firmly rooted in the second half of the nineteenth century. The recognition of the presidential power of removal, the granting by statute of the power of control to superior officers, and the statutory concentration of powers in lieads of departments have contributed to this continuing development.

II

\section{POWER OF CONTROL DERIVED FROM THE POWER OF REMOVAL}

"[T] $]$ he arbitrary form of dismissal," said Professor Wyman, "prevails [in centralized administration] because upon the whole it is experience that in no other way can an administration be maintained

head of department was that of an officer stationed at the centre of the government who inight have, it is true, in many cases the power of appointment and removal, but who was not supposed to direct the actions of the subordinates of his department . . . . The conception of a hierarchy of subordinate and superior officers was very dim if it existed at all." F. GoodNow, supra note 7, at 136-37. Virtually the same position prevailed in the administration of the states, id. at 137-38, and the local authorities, F. GoodNow, supra note 18 , at $228-31$.

37. See F. GoobNow, supra note 18 , at $60-62$.

38. See F. GoodNow, supra note 7, at 136-37.

39. See, e.g., United States ex rel. Stokes v. Kendall, 5 D.C. (5 Cranch) 163, 275 (D.C. Cir. 1837).

40. See, e.g., Orchard v. Alexander, 157 U.S. 372, $384-85$ (1895); Cornelius v. Kessel, 128 U.S. 456, 461 (1888); Barnard's Heirs v. Ashley's Heirs, 59 U.S. (18 How.) 43, 45 (1855). 
in a high state of efficiency. What is indispensable in centralized administration is instant obedience, which can be enforced only by this power of instant removal."41 Many subscribe to this view. Others, including distinguished students of political science and public administration, doubt the importance or usefulness of the power of removal. ${ }^{42}$ The real issue is the relative utility of disciplinary measures compared with other measures designed to promote administrative responsibility. No one, however, suggests that the administration slould or could function properly without the power to discipline, and ultimately to remove, insubordinate officials.

The power of reinoval is only one, albeit the most drastic, of several available disciplinary measures. ${ }^{43}$ Nevertheless, the following discussion will concentrate on the power of removal since it is the most effective disciplinary means of establishing superior control, and because other disciplinary measures are not often acknowledged in American administration.

The Constitution empowers the President, by and with the advice and consent of the Senate, to appoimt executive officers, and authorizes Congress to vest the appointment of inferior officers in the President or in the lieads of departments; ${ }^{44}$ but it does not expressly vest power in the President or department lieads to remove such officers. The courts, however, stated at an early date that as a general rule the power of removal is imcident to the power of appointmnent. ${ }^{45}$. For a time it was

41. B. WYMAN, supra note 6 , at 178.

42. See, e.g., C. Friedrich, supra note 7, at 397: "The power of dismissal is ... only one of many techniques for making official conduct responsible. In fact, dismissal is not even a particnlarly effective method for producing responsible conduct, but has many disadvantages and shortcomings, which ought to be considered for purposes of comparing the removal power with other means or techniques for producing responsibility." Professor Friedrich then discusses four additional types of measures which contribute to administrative responsibility, namely, promotional measures, financial measures of control and audit of expenditure, judicial measures based upon civil and criminal law, and the spirit of craftsmanship. Id. at 401-08.

43. "[B] efore the extreme penalty of dismissal or removal is applied, five other measures are available. They are reprimand, fine, temporary suspension, reduction of salary, and transfer to another, presumably less attractive, post. To neglect all these and to focus exclusive attention upon removal is like trying to set up a criminal law with capital punishment as the sole penalty." Id. at 399.

44. Clearly, the power to appoint and reappoint in itself may facilitate superior control. Its utility in this respect, however, is diminished by both legal (notably, the civil service law) and practical limitations. As Mr. Justice Brandeis pointed out in Myers v. United States, 272 U.S. 52, 265 (1926) (dissenting opinion), "[A] multitude of laws have been enacted which hmit the President's power to make nominations, and which, through the restrictions imposed, may prevent the sclection of the person deemed by him best fitted." See also E. CORWIN, supra note 8, at 70-79; REPORT OF THB President's Commitiee on AdministrattVe MaNagement 8-9 (1937).

45. In re Hennen, 38 U.S. (13 Pet.) 230 (1839). For the history of the President's power of removal, see Parsons v. United States, 167 U.S. 324 (1897). 
contested whether the President could remove, without the consent of the Senate, officers appointed by him and approved by the Senate. The issue was laid to rest when in 1833 President Jackson, without consulting the Senate, removed Secretary of the Treasury Duane, who had refused to exercise his statutory power to remove governmental deposits from the Bank of the United States in accordance with the President's order. Jackson appointed Taney in Duane's place, and Taney immediately carried out that order. ${ }^{46}$ The Supreme Court ultimately gave its imprimatur to the practice in the famous case of Myers $v$. United States $^{47}$ and held further that presidential removal power, being derived directly from the Constitution, could not be himited by Act of Congress. ${ }^{48}$ The President, it appears, may remove not only officers appointed by him but also, subject to statutory restrictions, officers appointed by department heads. ${ }^{49}$ It is this power of the President which has in fact given him almost complete control over the administration of the government. ${ }^{50}$

The power of department heads and other officials to remove of-

46. Commenting on this episode, Professor Wyman said: "This account of these events is worth a hundred cases from the law reports. The President it appears has the power in all matters whatsoever to force any officer whatsoever to do any act which the officer has power to do. He can dictate in all matters, because he has the power of instant dismissal without giving reasons therefor, and thereupon the right of immediate appointment without limitation therein. And this is true to a greater or to a lesser extent of the power of every superior over every inferior at every step in the hierarchy of a centralized administration. Might makes right." B. WyMaN, supra note 6, at 233.

47. 272 U.S. 52 (1926).

48. "The ordinary duties of officers prescribed by statute come under the general administrative control of the President by virtue of the general grant to him of the executive power, and he may properly supervise and guide their construction of the statutes under which they act in order to secure that unitary and uniform execution of the laws which Article III of the Constitution evidently contemplated in vesting general execution power in the President alone. . . . Finding such officers to be negligent and inefficient, the President should have the power to renlove thenl." Id. at 135. One important exception was laid down in Humphrey's Executor v. United States, 295 U.S. 602 (1935), holding that Congress could impose limitations upon the power of the President to renove officers performing quasi-judicial or quasi-legislative functions.

49. Wilmeth v. United States, 64 Ct. Cl. 368 (1928). See also O. Fresd, CrviL SERVICE LAW 180 (1939). Even if in theory the President could not remove officers not appointed by him, he could still in practice secure their removal through pressure (supported by the threat of removal) exerted on the department heads.

50. In the states the position is quite different from that in the federal administration. There a substantial number of department heads are elected by the people and may not be renioved by the governor. Often there are severe restrictions on the power of the governor to reniove even those department heads who are appointed by him. Statutory provisions which subject the department heads to the control of the governor are rare. All this makes for governments which are coinparatively decentralized and, according to many critics, rather weak and inefficient. See, e.g., F. GoodNow, supra note 7 , at 98-108, 129-33; C. RANSONE, THE OFFICE OF THE GoverNoR IN THE UNITED STAES ch. 8 (1956). 
ficers or employees appointed by them is more susceptible to curtailment than the power of the President. Their power is derived from statute and hence may be limited thereby. ${ }^{51}$ In fact, however, it has been hittle restricted. The principal limitations are those imposed by the Civil Service Act. ${ }^{52}$ Under the Act, a person to be removed from the classified civil service must be given notice, a copy of the charges, and opportunity to answer the charges in writing; but he is not entitled to an examination of witnesses or to a hearing. ${ }^{53} \mathrm{He}$ may be removed only "for such cause as will promote the efficiency of said service . ....54 This limitation, lowever, leaves the power of removal very broad. ${ }^{55}$ It clearly does not prevent removal for disobedience to lawful superior orders. ${ }^{50}$ Under this act removal becomes a more complicated and lengthy process, and superiors may (and, indeed, should) resort to it more cautiously; but it remains an effective weapon of control. ${ }^{57}$

The effectiveness of the removal power is enhanced by its decentralization. The power may generally be delegated by the Presi-

51. United States v. Perkins, 116 U.S. 483 (1886).

52. 22 Stat. 403 (1883) (codified in scattered sections of 5 U.S.C.).

53. 5 U.S.C. $\$ 7501$ (b) (Supp. IV, 1965-68). The Administrative Procedure Act $\$ 5$ exempts from the application of its provisions concerning hearing "the selection or tenure of an enuployee, except a hearing examiner appointed under section 3501 of this title." 5 U.S.C. $\$ 554$ (a) (2) (Supp. IV, 1965-68). See also 1 K. Davis, Administrative Law Treatise $\$ 7.13$ (1958). Cf., as to the discharge of veterans, Deving v. Canupbell, 194 F.2d 876 (D.C. Cir.), cert. denied, 344 U.S. 826 (1952).

54. 5 U.S.C. $\$ 7501$ (a) (Supp. IV, 1965-68).

55. This is especially so because of the rule that "The determination of whether or not a person's discharge would promote the efficiency of the Governnent service is vested in the administrative officer and no court has power to review his action if that action was taken in good faith." Gadsden v. Unitcd States, $111 \mathrm{Ct}$. Cl. 487, 489 (1948), cert. denied, 342 U.S. 856 (1951). See O. Field, CrviL Service LaW 181 (1939); Westwood, The "Right" of an Employee of the United States Against Arbitrary Discharge, 7 Geo. Wash. L. Rev. 212 (1938).

56. E.g., Schnidt v. United States, 153 Ct. Cl. 407, cert. denied, 368 U.S. 930 (1961). In MacMillan v. Morgenthau, 146 Misc. 588, 590-91, 263 N.Y.S. 568, 570-71 (Sup. Ct. 1933), the court said: "The fact that a subordinate believes that the affairs of a state department can be best administered by following the course of procedure which his own judgnent dictates, and therefore decides to disobey the orders of the head of his departnient, is not likely to impress any court. It is not for the subordinate to determine how the affairs of a state department should be administered. . . . and wilful disobedience of established rules or departmental orders pronulgated in good faith may well be cause for disnissal." And in Bailey v. Richardson, 182 F.2d 46, 58 (D.C. Cir. 1950), aff'd per curiam, 341 U.S. 918 (1951), it was said that "The criterion for retention or removal of subordinate enployees is the confidence of superior executive officials."

57. This is especially so since the Civil Service Act is inapplicable to persons whose appointment is excepted from the requirenent of competitive examinations. See 30 OP. ATT'Y GEN. 181 (1913). In fact subordinates having policymaking responsibilities are often excepted from this requirenent, and so lack even the protection of this Act. 
dent and the department heads, and then redelegated, so that it may ultimately rest with superior officers at a comparatively low level..$^{58}$

The power to remove generally assures that a subordmate will comply with his superior's instructions, whether they concern an act to be done or a modification or a revocation of an act already completed. ${ }^{59}$ The power of removal in practice, therefore, is normally equivalent to the power of direction. However, it is not exactly equivalent in law. When Attorney General Taney was asked in 1831 whether the President could lawfully direct a district attorney to discontinue a libel pending in the court, he answered in the affirmative. He added, however, that the President could only act through the district attorney, and if that officer refused to obey the direction, the President could not enforce it, except by removal of the disobedient officer, and the substitution of "one more worthy" in his place. ${ }^{60}$ Thus, when two years later Secretary of the Treasury Duane refused to obey President Jackson's order to remove federal deposits from the Bank of the United States, the President only obtained performance of his order by removimg Duane and replacing him with the more compliant Taney. Still later, in United States v. Kendall, ${ }^{61}$ the Circuit Court for the District of Columbia indicated that the power of removal, though facilitating control, was not equivalent to a statutory authority to control the subordinate. ${ }^{62}$

There appear to be no modern cases discussing whether the power of removal implies a direct power of control. If Kendall is still good law, the fact that the President or any superior officer may remove a departinent head or subordimate officer from office does not in itself

58. The President is now authorized generally to delegate his powers by the Presidential Subdelegation Act, 3 U.S.C. $\$ \S 301-303$ (1964). Heads of agencies (including the executive departments) are expressly authorized to delegate to subordinate officials their power in regard to employment, direction, and general administration of personnel under their agencies. 5 U.S.C. $\$ 302$ (Supp. IV, 1965-68). Other provisions in numerous statutes and reorganization plans are to the same effect. For an example of such a provision in a reorganization plan, see note 181 infra. See also Kempinski v. Greene, 189 F. Supp. 877 (E.D. Pa. 1960), aff'd 292 F.2d 820 (3d Cir. 1961).

59. There are, of course, those exceptional cases in which the threat of removal loses its effectiveness because of political or other practical considerations. Even Presidents have soinetimes had to yield to insubordinate Secretaries. See, e.g., R. NEUSTAdT, PResidential Power 36, 198 (1960).

60. 2 OP. AtT'Y GeN. 482 (1831).

61. 5 D.C. (5 Cranch) 163 (1837), aff'd, 37 U.S. (12 Pet.) 524 (1838).

62. "We cannot find a word in the law .... . [which vests] any authority in the President to prescribe his [the Postmaster-General's] duties, or to control him in the exercise of his official functions. It is true that he is appointed, and therefore may be removed, by the President. But the President, if he has the power to control him, can do it through his fear of removal. If he should so control him, no act done by him under that control, could be thereby justified." Id. at 189. For an account of the case, see note 34 supra. 
impose upon the subordinate a legal duty to obey his superior. Therefore, an act of the subordinate will not be considered unlawful merely because it is contrary to the superior's orders, and the courts will not compel the subordinate, by inandamus or otherwise, to coinply with such an order. In addition, the superior has no right to review (either upon appeal or on his own motion), to modify, or to annul the decision of the subordinate. ${ }^{63}$

The law apparently makes only one concession to the reahty of superior-inferior relationship. A subordinate decision will not be considered an unlawful abdication of discretion and will not be imvahdated inerely because it is rendered in comphance with a superior order. In other words, the law neither requires, nor does it generally forbid, a subordinate to act in obedience to the order of his superior. ${ }^{64}$ In practice, of course, the very fact that the subordinate may lawfully obey the order of his superior, coupled with the threat of removal if he does not obey it, is generally sufficient to ensure obedience.

The law is unsatisfactory, however, not only because it is divorced from reality, but also because it impedes sound administration in one important respect. The power of reinoval does not empower the superior to review the subordinate's decision either on appeal by an aggrieved member of the public or on his own notion. The superior, of course, may still informally review the decision, and although not entitled to substitute his own decision, may direct the subordinate to modify or annul it and the subordinate will presumably be inclined to coinply with that direction. The law, however, may not always allow the subordinate thus to reconsider and to modify or annul his decision. For example, the decision may have vested in a private imdividual a right or an interest of which lie may not be deprived, except on some special grounds, such as fraud. A mere change of mind in the particular case-even a change of policy-will not ordinarily entitle an officer to reconsider and to modify his original decision. ${ }^{65}$ A superior's

63. See J. Hart, The Ordinance Making Powers of the President of the Untred States 193-94 (1925; 2 B. Schwartz, A Commentary on the Constitution oF THE UNITED STATES, pt. 1, at 37 (1963). In one opinion Attorney General Cushing, speaking of heads of departments vested with statutory powers, said: "I hold that no Head of Department can lawfully perform an official act against the will of the President . ... 7 OP. ATT'Y GEN. 453, 469-70 (1855). If this means that an act of a department head against the will of the President is unlawful and possibly invalid, even in the absence of a statutory provision to that effect, then, it is subunitted, it is not correct. See F. GoodNow, supra note 7, at 81.

64. However, in exceptional cases, notably, where the subordinate performs a judicial function, he may be forbidden to abdicate his discretion and act upon a superior order. See, e.g., United States ex rel. Accardi v. Shaughnessy, 347 U.S. 260 (1954).

65. See, e.g., American Trucking Ass'ns v. Frisco Transportation Co., 358 U.S. 133 (1958). 
order inducing such a change of mind would probably fare no better. The result inay be awkward. The subordinate's decision, which through inadvertence or misunderstanding inay not conform to the superior's policy or instructions, or may otherwise be unlawful or undesirable, may be the final decision of the administrative agency. This may be detrimental, not only to the interests of the public, but occasionally also to the interests of the private individual. The subordinate, following the instructions of his superior, nay on another occasion consciously make an unjust decision, since he does not feel free to deviate from his instructions even in hard cases or in special circumstances not foreseen when the instructions were issued. Sound administration as well as justice requires that the decision should be subject to a formal review to enable the superior to correct errors and to allow deviations froin the instructions. To achieve that end, a special statutory provision is needed, explicitly placing the subordinate under the control of his superior. ${ }^{68}$

\section{III}

\section{POWER OF CONTROL EXPRESSLY GRANTED BY STATUTE}

In several statutes, the first Congress expressly vested in superior officers authority over subordinates. ${ }^{67}$ At a time when it was not yet acknowledged that the power of removal carried with it any power of control, it might well have been thought that such provisions were essential for maintaining efficiency and harmony within the administration. Without thein, each subordinate officer entrusted with statutory power was, in a sense, a law unto himself. ${ }^{68}$ The congressional practice

66. See, e.g., Orchard v. Alexander, 157 U.S. 372, 378 (1895): "It [the adjudication by the register and receiver of the General Land Office] was final when no supervising power was by statute vested in the Commissioner of the General Land Office. It ceased to be final when the general power of review and supervision of all 'executive duties' concerning the survey and sales of lands was vested in the higher officials of the Land Department at Washington."

67. E.g., Act of July 31,1789, ch. $5, \S 5,1$ Stat. 37: "It shall be the duty of the surveyor to superintend and direct all inspectors, weighers, ineasurers and gaugers within his district . . . and the said surveyors shall in all cases be subject to the control of the collector and naval officer." See, as to the control of the Presideut over soine executive departments, text accompanying notes 27-32 supra.

68. This was well explained by the Supreme Court in a case dealing with the disposition of public lands: "If the section declaring that proof in respect to settlement and improvement should be inade to the satisfaction of the local land officers, stood alone, as it fonnerly did, it might well be contended that as the local land officers were the ones to whose determination the question of settlement and improvement was confided, and as there was no statute granting any review of their determiuations, they must be taken as final. It was, or course, competent for Congress to give finality to their determinations, and having given thein the power to determine, and inade no provision for any review, it naturally followed that their judgment was final. It is not strange that the mischiefs liable to fiow from such a provision attracted the attention of 
of granting express powers of control continued even after it became evident that superior control was secured, to a great extent, by the existence of the power to remove disobedient officers. This was wholly reasonable, since, as noted earlier, control backed solely by the power of removal exhibits some conspicuous lacunae.

Today, there are express statutory provisions for superior control governing most of the powers vested by statute in officers or units of the executive brancli. ${ }^{69}$ Some statutes provide that certain heads of departments or other agencies are subject to the direction of the President. ${ }^{70}$

Congress. Great inequalities in the administration of the Land Department of the United States would inevitably ensue if the final determination of inatters connected with the sale and disposal of the public lands was left to a multitude of local land officers. The character and amount of testimony which would be held sufficient in one State and by one set of officers would be held insufficient in another State and by another set. Local influences might help or hinder individuals in acquiring titles to the public lands. Obviously, in order that equal justice might be administered, it was necessary that there should be a superintendence of all the actions of the local land officers and all the proceedings in the local land offices. And so it was that Congress made the several provisions which we have noticed for control by the general officers of the Land Department of proceedings for the survey, sale, and disposal of the public lands." Orchard v. Alexander, 157 U.S. 372, 384 (1895).

69. This has been done piecemeal. An attempt to enact a statute which would establisl the principle of superior control for the entire executive branch was made in 1949, when a bill entitled the General Executive Management Act was introduced in the Sonate. It classified the executive agencies of the Government as principal executive agencies (including the executive departments, the Government corporations and the independent agencies) and subordinate executive agencies (including the boards, bureaus, divisions, and other units that are in one of the principal executive agencies), and further provided that all such executive agencies, principal and subordinate, are inerely representatives of and acting for the President. It then stated: "whenever any function is vested by law in any such agency or in the liead thereof, such function is so vested merely for convenience. Such function should be treated as a function actually vested in the President and being exercised by the executive agency concerned, or the liead thereof, pursuant to authority so to do derived from delegations by the President. In connection with the exercise of any such function, the executive agency and the head thereof is (unless the function be quasi-judicial in nature) at all times subject, in respect of all natters relating to its exercise (including the time, manner, and extent of its exercise), to the direction and control of the President. In the case of subordinate executive agencies and the heads thereof, whenever any function is vested by law in any such agency or the head thereof, sucl function is, as hereinbefore provided, so vested merely for convenience, and is (unless it be quasi-judicial in nature) at all times subject, in respect of all matters relating to its exercise (including the time, manner, and extent of its exercise), to the direction and control not only of the President but also of the head of the principal executive agency in which such subordinate executive agency exists or of which it is an organizational unit." S. 942, 81st Cong., 1st Sess. \& 101(c) (1949). The bill was referred to the Senate Committee on Expenditures in Executive Departments, and there it quietly died. It should be observed that the proposed provision, otherwise in line with existing law and practice, would have placed under presidential control the so-called independent regulatory commissions, to the extent that they exercise functions which are not quasi-judicial in nature.

70. E.g., as to the Secretary of State, 22 U.S.C. $\$ 2656$ (Supp. IV, 1965-68); 
Almost all statutes establishing executive departments explicitly place them under the control of their chiefs. ${ }^{71}$ Similar provisions apply to some independent agencies. ${ }^{72}$ Frequently, statutes cliarge specified subordinate officers with the supervision of other inferior officers. ${ }^{73}$ In addition, some statutes include provisions authorizing Secretaries or other executive officials to give specific instructions to specified subordinate officers. ${ }^{74}$

The language employed by Congress in providing for administrative

Secretary of Defense, 10 U.S.C. $\$ 133$ (1964); Secretary of the Army, 10 U.S.C. $\S$ 3012(b)(5) (Supp. IV, 1965-68); Secretary of the Navy, 10 U.S.C. $\$$ 5031(b) (1964); Secretary of the Air Force, 10 U.S.C. $\$ 8012$ (b) (1964); Secretary of Transportation, 49 U.S.C. $\$ 1653$ (a) (Supp. IV, 1965-68); Administrator of General Services, 40 U.S.C. \& 751(b) (Supp. IV, 1965-68); Federal Civil Defense Administrator, 50 U.S.C. App. $\$ 2271$ (c) (1964); Administrator of Veterans' Affairs, 38 U.S.C. $\$ 210$ (b) (1964). Such provisions, however, are absent in statutes establishing the independent regulatory commissions.

71. E.g., as to the Secretary of the Treasury, 31 U.S.C. $\$ 1002$ (Supp. IV, 1965-68); Secretary of Defense, 10 U.S.C. $\$ 133$ (b) (1964); Postmaster General, 39 U.S.C. $\$ 501$ (1964); Secretary of the Interior, 43 U.S.C. \& 1451 (Supp. IV, 1965-68); Secretary of Agriculture, 7 U.S.C. $\$ 2202$ (Supp. IV, 1965-68); Secretary of Health, Education, and Welfare, 42 U.S.C. $\$ 3501$ (Supp. IV, 1965-68). The Secretaries of the military departments are placed under the control of the Secretary of Defense. E.g., 10 U.S.C. \& 5031(a) (1964) (Secretary of the Navy). For the effect of such a provision, see Congress Construction Corp. v. United States, 314 F.2d 527 (Ct. Cl. 1963).

In addition to such specific provisions there is a general provision concerning control by all heads of departments over their respective departments. 5 U.S.C. $\$ 301$ (Supp. IV, 1965-68) states: "The head of an Executive department or military department may prescribe regulations for the government of his department, the conduct of its employees, the distribution and performance of its business, and the custody, use, and preservation of its records, papers, and property ...." This section replaces 5 U.S.C. $\S 22$ (1964). See Notes of Decisions on Section 22 in 5 U.S.C.A.

Also, the statutes establishing the various departments commonly denote the Secretary as "the head" of the department. This in itself, however, has not been considered a grant of power to control the exercise of statutory powers by the officers of the department.

In the case of some departments the statutes do not expressly provide that the department shall be under the control of the Secretary. Such is the case with the departments first and last established-the Department of State, 22 U.S.C. ch. 38 (Supp. IV, 1965-68), and the Department of Transportation, 49 U.S.C. ch. 23 (Supp. IV, 1965-68). However, this does not mean that the officers of these departments are not in fact subject to the control of their Secretaries. The control in these cases is secured by other means-notably by the statutory concentration of all the powers and functions of the department in the hands of the Secretary. See Part IV infra.

72. E.g., to the Administrator of Veterans' Affairs, 38 U.S.C. $\$ 210$ (1964); and the Administrator of the National Aeronautics and Space Administration, 42 U.S.C. \& 2472(a) (1964).

73. E.g., the ex-officio commissioners for Alaska, 5 U.S.C. $\$ 121$ (1964); the Commissioner of Fish and Wildlife, 16 U.S.C. $\$ 742 \mathrm{~b}(\mathrm{~b})$ (1964); and the Solicitor of the Department of the Interior, 43 U.S.C. \& 1455 (Supp. IV, 1965-68).

74. E.g., 39 U.S.C. $\$ 4005$ (1964) (the Postmaster General may direct local postmasters to return to the senders mail addressed to a specified persou engaged in conducting a lottery). 
control varies. It may state that a Secretary shall discharge his functions "subject to the direction of the President";"75 or that a department shall be administered, or a particular officer shall act, "under the supervision and direction of the Secretary"; ${ }^{78}$ or that the Secretary shall "superintend generally the business of the department."77 The meaning of identical words or phrases may, of course, vary with their context. Thus, the construction placed by the court on one control provision need not necessarily govern another such provision, even if identical. ${ }^{78}$ Yet, it would seem unreasonable to make nice distinctions here between, e.g., "control," "supervision," and "superintendence." The statutes employing these and other similar terms were not enacted at the same time as one code, and it is obvious that Congress did not take paims to achieve uniformity of style. There is no indication that it intended to attach different meanings to these different terins, nor is there any reason for applying divergent rules of administrative control to the various departments. The courts have not, in fact, attached significance to the shght variations in the language of control provisions. ${ }^{70}$ It is possible, therefore, to ignore such variations, and attempt to determine generally the effect which inay be attributed to such statutes.

\section{A. Discretionary Nature of Control Power}

The Supreme Court has stated: "If the Secretary is charged by law with the performance of such a duty, he is bound to fulfill it. It is imperative, not discretionary. He cannot discharge it, according to the intention of the statute, in a manner either arbitrary or perfunctory." ${ }^{80}$ This statement should not be taken literally. There may, indeed, be a moral or political duty to exercise the power of control. It is not, however, coupled with a legal duty. Statutory provisions granting that

75. E.g., 10 U.S.C. § 133 (1964).

76. E.g., 42 U.S.C. \$ 3532 (Supp. IV, 1965-68).

77. E.g., 39 U.S.C. $\& 501$ (1964). In some cases statutes grant the power of control not expressly but impliedly or indirectly. For example, it is provided that the Secretary of Labor is the head of the Department of Labor and, further, that specified bureaus and offices "shall be under the jurisdiction and supervision of the Department of Labor.” 29 U.S.C. $\$ \S 551,557$ (Supp. IV, 1965-68).

Of a different character altogether are provisions which grant only a limited, as distinguished from general, power of control. Thus, a statute may provide that a certain class of decisions is subject to the "approval" of, or an "appeal" to, a superior officer. The effect of such provisions will not be dealt with here. Suffice it to notice that they will generally be of a much more restricted effect than provisions granting general power of control. For example, a board which was empowered to entertaiu appeals was held incompetent to undertake review on its own motion. Peters v. Hobby, 349 U.S. 331 (1955).

78. See Butterworth v. United States ex rel. Hoe, 112 U.S. 50, $56-57$ (1884).

79. E.g., Christgau v. Fine, 223 Minn. 452, 27 N.W.2d 193, 198 (1947).

80. Butterworth v. United States ex rel. Hoe, 112 U.S. 50, 57 (1884) (dictum). 
power are generally phrased in a permissive or neutral, rather than in an imperative, mode. More important, the power of control is essentially discretionary. It should be left to the responsible official to determine when and how to exercise it, whether by general rule or by individual order, and what the contents of his instructions should be. Intervention would involve the judiciary deeply in the day-to-day operations of the executive branch. It is unlikely that a court would issue a mandamus to coinpel an officer to exercise his power of control in any particular case or manner, ${ }^{81}$ although this is not to say that a court will not intervene to review the legality of instructions given in pursuance of that power. ${ }^{82}$

\section{B. Control Through Regulations}

The discretion inherent in the power of control allows the responsible official to determine, among other matters, the mode in which control will be exercised. For example, he may consider in each instance whether to order a rehearing, to require the approval of some higher officer, or personally to hear and to determine the case by way of appeal. As a general rule, however, such unsystematic control is plainly inefficient, if not impractical. Ordinarily, the more reasonable course of action is for the responsible official to stipulate by regulations the mode of control, as he is normally entitled to do ${ }^{83}$ Such regulations inay provide, for example, that the decisions of a certain subordinate shall be subject to the approval of the officer charged with control or of another specified officer; that they may be appealed; that there shall be one or several levels of appeal; or that a special board shall be constituted for the determination of such appeals. They may also prescribe the forms, the time limit, and other procedural requirements of appeal. ${ }^{84}$

Ordinarily, the regulations prescribe not only how control shall be exercised but also who shall exercise it. It has been recognized that it

81. As to whether a court may order a superior to entertain an appeal from the decision of his subordinate, see text accompanying notes 96-105 infra.

82. On such review, see text accompanying notes 147-53 infra.

83. "The mode in which the supervision shall be exercised in the absence of statutory direction may be prescribed by such rules and regulations as the Secretary may adopt." Knight v. United States Land Ass'n, 142 U.S. 161, 178 (1891). Also see B. WYMAN, supra note 6 , at 304 . In practice, however, it will rarely be necessary to rely directly npon the power of control as an authority for such regulations, since generally statutes expressly einpower department heads to issue regulations for the execution and enforcement of statutes entrusted to their administration. See, e.g., 43 U.S.C. $\$ 1201$ (1964); 43 C.F.R. pt. 1840. See also 5 U.S.C. $\$ 301$ (Supp. IV, 196568), supra note 71.

84. See, e.g., Butterworth v. United States ex rel. Hoe, 112 U.S. 50, 57-58 (1884); McDaid v. Oklahoma, 150 U.S. 209 (1893). Generally, the procedure in "administrative appeals" is much less rigid and cumbersome than in "judicial appeals". See, e.g., Christgau v. Fine, 223 Minn. 452, 27 N.W.2d 193 (1947). 
is practically impossible for high officials personally to effectuate control over all matters assigned to their subordinates. Hence, the regulations may provide that soine designated officer shall exercise control, by way of approval, or appeal, or otherwise, subject to such restrictions and supervision as may be deemed advisable. ${ }^{85}$ The courts will generally uphold such a provision even if it is considered a delegation of power ${ }^{80}$ In most cases, however, it will be unnecessary to examine whether or not it is a lawful delegation, since it may be regarded as a proper exercise of the power of control by the responsible official himself-an act of control establishing machinery for control. The various persons who constitute the components of that inachinery act in behalf of their superior in whoin that power has been originally vested; their acts are deemed to be his acts. ${ }^{87}$

Regulations, as well as individual orders, made in pursuance of the power of control are binding upon subordinate officers. ${ }^{88}$ Generally, they also bind the official who promulgated them: As long as they are in force he may not disregard or deviate from thein in any particular case. $^{88}$ He may, however, at any time revoke or amend them according to need and circumstance. ${ }^{.0}$

\section{Control by Way of Review}

Superiors may exercise control through review of subordinate de-

85. Williams v. United States, 42 U.S. (1 How.) 290, 296-98 (1843); Snyder v. Sickles, 98 U.S. 203, 210-11 (1878); United States v. Schlierholtz, 133 F. 333, 334-35 (E.D. Mo. 1904); United States v. Warfield, 170 F. 43, 45 (4th Cir. 1909); 3 OP. ATT'Y GEN. 137 (1836); 36 Op. ATT'Y GEN. 456, 461-62 (1931); 40 Op. ATT'Y GEN. 27 (1941). In fact, subordinate officers commonly exercise the power of control, and notably the power to hear appeals, on behalf of the Secretary. See, e.g., the volumes of Decisions of the Department of the Interior (Interior Dec.).

86. For the authority of the President and the heads of agencies to delegate their power, see note 58 supra. Also see Morrow v. Clayton, 326 F.2d 36 (10th Cir. 1963); The Dredge Corp., 65 Interior Dec. 336 (1958). Other officials may delegate their power of control, much as any other of their powers, only where the statute conferring that power expressly or impliedly authorizes then so to do.

87. United States v. Warfield, 170 F. 43, 45 (4th Cir. 1909).

88. Id.; Ex parte Williams, 277 F. 819, 821 (S.D. Ohio 1921). Also see F. GoodNow, supra note 7 , at 143 . Private persons doing business with the agency are also bound by them, in the sense that they are not entitled to demand review of a subordinate decision in any way inconsistent with the regulations. See id.; Morrison v. McKissick, 5 Interior Dec. 245 (1886); M.H. Lichtenwalner, 69 Interior Dec. 71, 72 (1962).

89. See, e.g., United States ex rel. Accardi v. Shaughnessy, 347 U.S. 260 (1954). See generally Berger, Do Regulations Really Bind Regulators?, 62 Nw. U.L. REV. 137 (1967). But see Kingsland v. Carter Carburetor Corp., 168 F.2d 565 (D.C. Cir.), cert. denied, 335 U.S. 819 (1948). See also note 94 infra.

90. E.g., Lytle v. Arkansas, 50 U.S. (9 How.) 314, 332 (1850); United States v. Cobb, 11 F. 76 (C.C. Mass. 1882); George W. Dally, 41 Interior Dec. 295, 298-99 (1912). 
cisions. In the first place, an aggrieved individual nnay appeal the decision of the subordinate to his superior. Many statutes expressly provide for such appeals. ${ }^{91}$ The absence of a statutory provision to that effect, however, does not preclude an appeal. Rather, the authority of the superior officer to entertain appeals in such cases is regarded as imphicit in his power of control.

If appeal were the only method of superior review, it is apparent that a subordinate decision favorable to the private claimant would be final in fact, even if it were unreasonable, legally erroneous, or inconsistent with official policy. To avoid this result, the superior generally has authority to review the decision on his own motion, even if the private party objects. ${ }^{92}$ The fact that the relevant statute expressly provides for an appeal but is silent as to review on the nnotion of the superior does not exclude review by implication. ${ }^{93}$

Since the superior may undertake review on his own motion, it would seejn to follow that he may also entertain an appeal where no

91. See E. Freund, Admintstrative Powers over Persons and Property 270-74 (1928); 2 AM. JUR. 2d, Administrative Law \$ 539 (1962).

92. "When proceedings affecting titles to lands are before the Department the power of supervision may be exercised by the Secretary, whether these proceedings are called to his attention by formal notice or by appeal. It is sufficient that they are brought to his notice. . . . For example, if, when a patent is about to issue, the Secretary should discover a fatal defect in the proceedings, or that by reason of some newly ascertained fact the patent, if issued, would have to be annulled, and that it would be his duty to ask the Attorney General to institute proceedings for its annulment, it would hardly be serionsly contended that the Secretary might not interfere and prevent the execntion of the patent. He could not be obliged to sit quietly and allow a proceeding to be consummated, which it would be immediately his duty to ask the Attorney General to take measures to annnl. It would not be a sufficient answer against the exercise of his power that no appeal had been taken to him and therefore he was without authority in the matter." " Knight v. United States Land Ass'n, 142 U.S. 161, 178 (1891), quoting Pueblo of San Francisco, 5 Interior Dec. 483, 494 (1887). See also Magwire v. Tyler, 66 U.S. (1 Black) 195 (1862); Stockley v. United States, 271 F. 632, 639-40 (5th Cir. 1921); Idaho Desert Land EntriesIndian Hill Group, 72 Interior Dec. 156, 177 (1965); Joseph Bnrstyn, Inc. v. Wilson, 303 N.Y. 242, 253-54, 101 N.E.2d 665, 670 (1951), rev'd on other grounds, 343 U.S. 495 (1952).

93. In Hull v. Commissioner of Patents, 9 D.C. (2 MacArth.) 90 (1875), it was contended before the Supreme Court of the District of Columbia that, in the absence of a formal appeal as prescribed by statute, the decision of the examiners-in-chief, favorable to the applicant, is final and binding upon the Commissioner of Patents. To this Mr. Justice Olin answered: "The interpretation contended for would turn the head of the office into the tail. ... The relator's counsel has dwelt upon the fact that the law does not expressly give the Commissioner the right of appeal from the decision of the examiners-in-chief, and has nrged this as proof that such action is final. This does not seem to me to be the proper inference. I think the right of appeal was omitted because it was unnecessary to confer it; for the Commissioner's snpervisory power over acts of the subordinates in the office is such as to preclude any necessity of his 'appealing' from the examiners-in-chief." Id. at 108. See also Morgan v. Hines, 113 F.2d 849, 850 (D.C. Cir. 1940). 
right of appeal has been granted by regulation or practice, and also, where such a right is granted, if the appeal does not conform to the prescribed requirements, relating, for example, to time limit or form. ${ }^{04}$ Even if the superior may not entertam an appeal which violates the regulations, he may still take such an appeal as if it were a review on his own motion, outside the scope of the regulations, and valid as such. ${ }^{05}$

Correlative to the power of the superior to review subordinate decisions is the right of a citizen, aggrieved by a subordinate's decision, to demand superior review. In many cases, sucl a right is expressly prescribed by statute or regulations, and may be enforced by mandamus. ${ }^{\circ B}$ But is there such a right notwithstanding the absence of legislative provision? In a dictum, the Supreme Court answered the question in the affirmative in Butterworth $v$. United States ex rel. Hoe::77

While it may be admitted that, so far as the public alone have an interest in the proper performance by the Commissioner [of Patents] of his duties in the administration of his bureau, the Secretary [of the Interior] might satisfy his duty of direction and superintendence by prescribing general rules of conducting the public business and securing, by general oversight, conformity to them; yet, on the other hand, it must also be admitted, that whenever a private person acquires by law a personal interest in the performance by the Commissioner of any act, he thereby also acquires an individual interest in the direction and supervision of the Secretary, to correct any error, or supply any omission or defect in its performance, tending to his imjury. It is a maxim of the law, admitting few if any exceptions, that every duty laid upon a public officer, for the benefit of a private person, is enforceable by judicial process. So that the Secretary would be bound, upon proper application, in every such instance, to inquire into, and if necessary redress, the alleged grievance. And hence the official duty of direction and supervision on the part of the Secretary implies a correlative right of appeal from the Commissioner, in every case of complaint, although no such appeal is expressly given.

Professor Goodnow, relying on this dictum, is of the opinion that a

94. "The rules prescribed are designed to facilitate the Department in the despatch of business, not to defeat the supervision of the Secretary." Knight v. United States Land Ass'n, 142 U.S. 161, 178 (1891), quoting Pueblo of San Francisco, 5 Interior Dec. 483, 494 (1887). See also Kingsland v. Carter Carburetor Corp., 168 F.2d 565 (D.C. Cir.), cert. denied, 335 U.S. 819 (1948); Gage v. Gunther, 136 Cal. 338, 68 P. 710 (1902).

95. "It makes no difference whether the appeal is in regular form according to the established rules of the Department, or whether the Secretary on his own motion, knowing that injustice is about to be done by some action of the Commissioner, takes up the case and disposes of it in accordance with law and justice." Knight v. United States Land Ass'n, 142 U.S. 161, 181 (1891). See also Morrison v. McKissick, 5 Interior Dec. 245 (1886).

96. E.g., United States ex rel. Steimmetz v. Allen, 192 U.S. 543 (1904).

97. 112 U.S. 50,57 (1884). 
right of appeal does exist. ${ }^{98}$ On the other hand, Professor Ernst Freund, citing no authority, believes that no such right exists. ${ }^{98}$ The question is thus open to argument.

It may be argued that the dictum in the Butterworth case cannot stand once it is agreed that the notion upon which it is based-that power of control is ministerial and not discretionary-is without ground. ${ }^{100}$ Clearly, if the power is discretionary, it should ordinarily be up to the superior official to determine whether or not to grant review of any particular decision. Moreover, generally speaking, it would appear that the main purpose of Congress in conferring the power of control upon superior officials has been to secure efficiency and harmony within the administration, and thus to serve the public rather than private interests. ${ }^{101}$ If so, private persons should not be permitted to compel review where the responsible official is of the opinion that review is unnecessary or would unduly burden the agency in the discharge of its duties. Private persons admittedly have a legitimate intercst in the proper disposition of their cases by the administration, but their interest may be adequately protected through judicial review.

Review by the courts, however, is likely to be inore expensive, more time-consuming, and much nore narrow in scope than administrativc review. A court is concerned solely with the legality of administrative action, whereas a superior official inay also annul a subordinate decision which is unjust, inconsistent with official policy, or otherwise undesirable. Indeed, the limitations imposed on the scope of judicial review are justified partly by the existence of a much broader administrative review. ${ }^{102}$ Although administrative appeals add to the labor of the administration, the corresponding reduction in the number of judicial review proceedings that the administration must defend may well counter-balance this added burden. Also, administrative appeals do not necessarily delay administrative action, since it is in the discretion of the subordinate or the superior officer to determine whether to suspend the operation of a decision pending review.

On balance, however, it is very doubtful that a court would compel

98. F. GoodNow, supra note 7, at 91, 146.

99. E. FREUND, supra note 91 , at 271.

100. See text accompanying note 80 supra.

101. "[Administrative control] is exercised primarily in the interest of governmental efficiency, though it may be used subsidiarily in the interest of the protection of private rights and the furtherance of the public welfare. Its main endeavor is to obtain harmony in administrative action, efficiency in the service in general, and uprightness and competence in the officials." 2 F. GoodNow, supra note 18, at 140 . See also Knight v. United States Land Ass'n, 142 U.S. 161, 181 (1891); Orcliard v. Alexander, 157 U.S. 372,384 (1895).

102. "[I]f [administrative control] is well developed it will not be necessary to develop so fully the other means of control." 2 F. GoodNow, supra note 18, at 141. 
a superior official to hear and determine an appeal in the absence of a congressional provision to that effect, ${ }^{103}$ if only because one may generally assume that a superior official who has persistently declined to review the decision of his subordinate has tacitly approved that decision on its merits. If so, an appeal ordered by the court would probably be a useless formality. ${ }^{104}$

Even if there exists a right of administrative appeal, it does not follow, as the dictum in the Butterworth case might be thought to imply, that the official charged by statute with the power of control should personally entertain the appeal. Such a duty would create too heavy a burden. Hence, the official may discharge any such duty by assigning a subordinate to hear and determine the appeals. ${ }^{105}$

There is no uniform scope of review when a subordinate decision is examined by a superior either on appeal or on his own motion. Of course, where review is expressly prescribed by statute, the language and purpose of the relevant statutory provision will determine its scope. ${ }^{106}$ Where, however, review emanates from the general power of control, its scope will depend in each instance on the discretion of the official vested with that power. ${ }^{107}$ For one class of cases he may provide a review limited to certain matters, such as correction of errors of law or fact, or securing conformity with officially declared policy, and for another class of cases a much broader review. ${ }^{108}$ The reviewing

103. See Rizzi v. Murff, 171 F. Supp. 362 (S.D.N.Y. 1959).

104. $C f$., as to the right of a person to demand a rehearing or a reconsideration of his case by the authority which had determined it, $1 \mathrm{~K}$. Davis, supra note $53, \S 8.18$.

105. No appeal would ordinarily lie to the President from the decision of the head of a department, on the theory that the President acts through the heads of the departments, and their decisions are in law his own decisions. See 9 OP. ATT'Y GEN. 462 (1860); $10 \mathrm{id} .526$ (1863); $15 \mathrm{id} .94,100-102$ (1876). This theory may be applicd as well to other officials. See, e.g., 40 id. 27 (1941).

106. See, e.g., Fisher v. Alwen, 290 F. 8 (9th Cir. 1923).

107. "It is characteristic of all administrative appeals that they extend to every phase of the original decision, unless especially restrieted; they therefore may not only consider new evidence but may cover matter of discretion. It may be that where they are to be conducted under rules, the rules may impose restrictions in these respects; however, practices in that respect cannot be ascertained from the statute books." E. FrEUND, supra note 91, at 276. "It is also probable, although not certain, that the Secretary would be slower to interfere with a discretionary power than with an erroneous decision. The whole matter is obviously in the main one of departinental practice." Id. at 271.

108. As the Supreme Court noted: "The Commissioner of the General Land Office exereises a general superintendence over the subordniate officers of his department, and is clothed with liberal powers of control, to be exercised for the purpose of justice, and to prevent the consequences of inadvertence, irregularity, mistake, and fraud." Bell v. Hearne, 60 U.S. (19 How.) 252, 262 (1857). See Barney R. Colson, 70 Interior Dec. 409, 412 (1963); cf., e.g., Boesche v. Udall, 373 U.S. 472 (1963) (administrative error); United States ex rel. Miller v. Black, 128 U.S. 50 (1888) (application of statutory provisions to facts); Shepley v. Cowan, 91 U.S. 330, 340 (1875) 
officer may even hear the case de novo and substitute his decision for that of the subordinate on virtually any ground. ${ }^{109}$

The reviewing official also possesses broad remedial powers. He ordinarily may amend, reverse, annul or affirm the decisions of the subordinate; ${ }^{: 110}$ remand the case for further hearing or for a rehearing; ${ }^{111}$ suspend the operation of the subordinate decision pending review or rehearing:112 reconsider his own decision or the decison of his predecessor: ${ }^{113}$ or issue a clarifying decision when it becomes apparent that the parties affected do not understand the import of his earlier decision. ${ }^{114}$ In sun, the review by superior officials enabled by the power of control is so flexible and broad as to satisfy all reasonable needs of the administration in this respect, as well as to afford considerable protection to citizens against excesses by subordinate officers. ${ }^{115}$

\section{Control by Way of Direction ${ }^{116}$}

The power of control would not be complete if it did not include the power of direction. ${ }^{117}$ If a superior were allowed to review and

(determination of facts); Morrow v. Clayton, 326 F.2d 36 (10th Cir. 1963) (fraud); Gage v. Gunther, 136 Cal. 338, 68 P. 710 (1902) (error of law).

109. "[The Secretary of the Interior] has supervisory powers over all the officials below him, and is the final arbiter of all questions of fact. Hence the conclusion of the register and the receiver is, at best, but advisory. The commissioner is not bound by it, and the secretary is not bound by the judgment of either the local land officers or of the commissioner. He tries the case de novo, and decides upon the testimony presented to him . . . " Lawrence v. Potter, 22 Wash. 32, 39, 60 P. 147, 149 (1900).

110. See Knight v. United States Land Ass'n, 142 U.S. 161, 178 (1891). See also United States v. Standard Oil Co. of California, 20 F. Supp. 427, 447-48 (S.D. Cal. 1937).

111. E.g., Orchard v. Alexander, 157 U.S. 372 (1895).

112. E.g., Williams v. Newman, 257 F. 353, 356 (D. Ore. 1919). Cf. Administrative Procedure Act $\$ 10$ (d), 5 U.S.C. $\$ 705$ (Supp. IV, 1965-68) (power of agency to postpone the effective date of any action taken by it pending judicial review).

113. E.g., West v. Standard Oil Co., 278 U.S. 200, 210 (1929); B.E. Burnaugh, 67 Interior Dec. 366 (1960); Gage v. Gunther, 136 Cal. 338, 68 P. 710 (1902). A statutory provision to the effect that the decision of the Secretary "shall be final and conclusive" does not necessarily deprive the Secretary of the power to reconsider and subsequently reverse his decision. Lane v. United States ex rel. Mickadiet, 241 U.S. 201, 208-10 (1916); United States v. Bentley, 107 F.2d 382 (2d Cir. 1939); cf. Brownell v. Tonı We Shung, 352 U.S. 180, 184-85 (1956); Johnson v. Towsley, 80 U.S. (13 Wall.) 72, 82-83 (1872). See generally on rehearings and reconsideration 2 K. Davis, supra note $53, \S 18.09$.

114. E.g., United States v. Baranof Exploration \& Development Co., 72 Interior Dec. 212, 216 (1965).

115. Further details concerning the practice on administrative review may be found in collections of administrative decisions. See, e.g., the volumes of Decisions of the Department of the Interior (Index-Digest, "Rules of Practice.")

116. On the power of direction of the President, see generally J. HART, THE Ordinance Maring Power of the President passim (1925).

117. "Responsibility and accountability are impossible without authority-the 
annul the decisions of his subordinates, but not to direct their course of action in advance, it would greatly impair predictability and uniformity of administrative action and would greatly increase both the need for and the difficulty of administrative review. In fact, direction is probably far inore important to the proper functioning of the administration than review, much as prevention is superior to cure.

The power to issue directions is, indeed, an integral part of the power of control. ${ }^{118}$ The superior may einploy it in two principal ways. First, he may issue individual orders, according to the need and circumstances of each particular case. Thus, the superior may order his subordinate to determine a certain claim or to initiate certain proceedings. ${ }^{119}$ Generally, he may also intervene in a case pending before a subordinate, either by ordering the case transferred to him for hearing and decision, or by telling the subordinate what decision to render. ${ }^{120}$ Secondly, the superior may issue general instructions, concerning both the form and the substance of the subordinate's action in a specified class of cases. ${ }^{121}$ The instructions are binding upon the

power to direct. The exercise of authority is impossible vithout a clear line of command from the top to the bottom, and a return lime of responsibility and accountability from the bottom to the top." Hoover COMM'N REPORT, supra note 2, at 3 .

118. As the Supreme Court has stated, "[I]f the power and duty of the Secretary [of the Interior], in directing and superintending the performance by the Commissioner [of Patents] of his duties, and those of all other subordinates in the bureau, may be exercised in the form of appeal, it may also be exercised in any other mode, in the discretion of the Secretary, suitable to the end in view; for, if directing and superintending include review by appeal after a decision, they may as well embrace dictating, either in advance of action or from time to time, during its course and progress." Butterworth v. United States ex rel. Hoe, 112 U.S. 50, 58 (1884). See id. at 57; Knight v. United States Land Ass'n, 142 U.S. 161, 178 (1891) ("[S]upervision may bo exercised by direct orders or by review on appeals."). Often statutes expressly provide for the power of direction. For example, "The Administrator [of Veterans" Affairs], under the direction of the President, is responsible for the proper execution and administration of all laws administered by the Veterans' Adıninistration and for the control, direction, and management of the Veterans' Administration." 38 U.S.C. \$ 210(b) (1964). Also, "[T]he Postmaster General shall . . . instruct all persons in the Department with reference to their duties." 39 U.S.C. \& 501 (1964). In many cases, however, the power of direction is derived wholly from the general power of control. Directions may also be called instructions, orders, regulations, directives, circulars, etc.

119. E.g., Duguid v. Best, 291 F.2d 235, 241 (9th Cir. 1961).

120. "[I]n every case of an application for a patent, or for a reissue, or for an extension, or in cases of an interference, the Secretary may direct the matter to bo heard before himself, and thereupon further direct what decision shall be rendered in each matter by the Commissioner, so as to meet his approval." Butterworth v. United States ex rel. Hoe, 112 U.S. 50, 58 (1884). See, e.g., West v. Standard Oil Co., 278 U.S. 200, 213 (1929); Guaranty Savings Bank v. Bladow, 176 U.S. 448, 452 (1900); Congress Constr. Corp. v. United States, 314 F.2d 527 (Ct. Cl. 1963); Public Service Co. of New Mexico, 71 Interior Dec. 427 (1964); United States v. Browning, 68 Interior Dec. 183 (1961); George W. Dally, 41 Interior Dec. 295, 299 (1912).

121. See, e.g., Cosmos Exploration Co. v. Gray Eagle Oil Co., 190 U.S. 301 
subordinates, ${ }^{122}$ but the superior may, of course, revoke or change them. ${ }^{123}$

Instructions play a most important role in the working of the administration. They are generally voluminous and may go into minute detail, considerably curbing the discretion and, inevitably, as well the flexibility and initiative of subordinate officers. ${ }^{124}$ Indeed, as instructions often appear to be unduly detailed and rigid, the basically sound principle of superior direction may now have been carried so far as to be in need of reform. ${ }^{125}$

\section{E. Enforcement of Superior Orders}

It would be an exceptional case for a subordinate officer, who by express statutory provision is placed under the control of his Secretary or another superior officer, openly to disobey any lawful order of his superior. ${ }^{128}$ Should it happen, however, the superior generally has ample power at his disposal to assure that his order is carried out. $\mathrm{He}$ may divest the disobedient officer of the matter and deal with it himself or transfer it to another officer, ${ }^{127}$ or he inay take disciplinary measures, the unost drastic of which is the removal of the disobedient officer followed by the appoimtment of another who will presumably abide by the order. ${ }^{128}$ A private individual aggrieved by the refusal of a subordinate officer to act in compliance with a superior order may, and usually will, apply first to the superior officer to have him exert his influence or pressure. He may also apply to the court for an order of mandamus against the subordinate officer. ${ }^{129}$ The combined effect of these sanctions is usually quite adequate to ensure obedience by the

(1903); United States v. Cobb, 11 F. 76 (C.C. Mass. 1882); Ex parte Willman, 277 F. 819,821 (S.D. Ohio 1921). Also see F. Goodnow, supra note 7, at 143; B. WyMAN, supra note 6 , at 304-06.

122. See note 88 supra.

123. See note 90 supra.

124. "It is a common remark by practitioners before the land department that the land laws 'do not amount to anything, but that everything depends upon the instructions." " Pierce v. Frace, 2 Wash. 81, 99, 26 P. 192, 207 (1891) (Dunbar, J. dissenting). See H. Kaufman, ThE Forest RANGer 94-102 (1960).

125. See Hoover COMM'N REPORT, supra note 2, at 4-7.

126. As far as the Court is concerned, "[M] andamus evidently will not lie to compel a public officer to do a particnlar thing which his superior in authority has lawfully ordered him not to do." Butterworth v. United States ex. rel. Hoe, 112 U.S. 50, 54 (1884).

127. See note 120 supra.

128. See Part II supra.

129. "As a general rule, when a superior tribunal has rendered a decision binding on an inferior, it becomes the ministerial duty of the latter to obey it and carry it out. So far as respects the matter decided, there is no discretion or exercise of judgment left. This is the constant course in courts of justice. The appellate court will not hesitate to issue a mandamus to compel obedience to its decisions. 
subordinate to the lawful orders of his superior. Indeed, though the existence of these sanctions is important, they are rarely used in practice, partly because confidence in the superior, identification with the values of the administrative unit, and mental acceptance of a legitimate authority generally prevent disobedience to superior orders. ${ }^{130}$

\section{F. Restrictions Upon Power of Control}

Of course the power of control, although broad, has its limitations. Factors which militate against the acceptability of superior orders, such as a conflict between the superior order and the personal interests or the personal values of the subordinate, constitute practical limitations. ${ }^{131}$ In addition, there are legal limitations.

Some subordinates are not subject, in law, to the control of their superiors. This may be the case where there is no statutory provision subjecting the subordinate to superior control, ${ }^{132}$ where a statutory provision expressly exeenpts a subordinate froin such control; ${ }^{133}$ or, in exceptional cases-notably, when the subordinate exercises judicial powers-even where he is expressly placed under the control of his superior. ${ }^{134}$

"The appellate tribunal in the present case is the Secretary of the Interior, who has no power to enforce his decisions by mandamus, or any process of like nature; and therefore a resort to a judicial tribunal would seem to be necessary, in order to afford a remedy to the party injured by the refusal of the Commissioner [of Pensions] to carry out his decision. But it is suggested that removal of the contumaeious subordinate from office, or a civil suit brought against him for damages, would be effectual remedies. We do not concur in this view. A suit for damages, if it could be maintained, would be uncertain, tedious, and ineffective remedy, attended with inany contingencies, and burdened with onerous expenses. Removal from office would be still more unsatisfactory. It would depend on the arbitrary discretion of the President, or other appointing power, and is not such a remedy as a citizen of the United States is entitled to demand. We think that the case suggested by the petition is one in which it would be proper for the court to interfere by inandamus." United States ex rel. Miller v. Black, 128 U.S. 50, 52 (1888). In subsequent proceedings the Court held that, on the merits of the case, a mandamus should be refused. United States $e x$ rel. Miller v. Raum, 135 U.S. 200 (1890).

130. See H. Simon, D. Smithidurg \& V. Thompson, Public Administration 188-201 (1950); H. KAUFMAN, supra note 124, at 94.

131. See H. Simon, D. Smithburg \& V. Thompson, supra note 130 , at 184-85. See also Commission on Organization of the Executive Branch of the Government, Task Force Report on Departmental Management 35-36 (1949) [hereinafter TASK FORCE REPORT].

132. The independence of the regulatory commissions, such as the Federal Trade Commission, is primarily the result of limitations upon presidential power to remove members of such commissions and the absence of statutory provisions subjecting the commissions to presidential control.

133. E.g., Departinent of Transportation Aet \& 5(f), 49 U.S.C. \& 1654(f) (Supp. IV, 1965-68): "In the exercise of its functions, powers, and duties, the [National Transportation Safety] Board shall be independent of the Secretary and the other offices and officers of the Department."

134. See, e.g., Butterworth v. United States ex rel. Hoe, 112 U.S. 50 (1884). 
In other cases both substantive and procedural restrictions may hedge the power of control which exists. Of course, a superior should not exercise the power of control so as to violate any statutory or constitutional provision. ${ }^{135}$ A superior may not by his order lawfully prevent the execution of a ministerial duty imposed by legislation on the subordinate. If the subordinate is, nevertheless, imclined to obey such an order, a court may intervene and issue a mandamus to compel him to perform his duty. ${ }^{136}$ Where a discretionary power is vested by law in a subordinate, the superior may indeed instruct the subordinate how to exercise the discretion, but he may not by his order cause the subordinate to overstep the limits of that power. If he does, a court may grant an imjunction to restrain the subordmate from acting in comphance with that order. ${ }^{137}$ Also, statutes conferring the power of control occasionally expressly impose restrictions on the exercise of that power. Such restrictions must be observed if the superior order is to be lawful and valid. ${ }^{138}$

Time may also limit the power of control. As long as the department is seized of a matter and no final decision has been made, the superior may exercise control by way of direction or review. He may do so even where a private individual relied on the initial decision of the subordinate, acted upon it, and will be imjured if that decision is subsequently reversed by the superior. ${ }^{139}$ Once the department makes a final decision and the private individual thereby acquires a vested right, however, the superior generally may not exercise his power so as to deny that right. ${ }^{140}$ If a reasonable measure of stability in dealing with

135. Further, it should not generally be exercised in violation of regulations, even if made by the superior himself. See, e.g., Uinted States ex rel. Accardi v. Shaughnessy, 347 U.S. 260 (1954). See note 89 supra.

136. See Campbell v. United States, 107 U.S. 407 (1882); United States v. Schurz, 102 U.S. 378 (1880); Kendall v. United States ex rel. Stokes, 37 U.S. (12 Pet.) 523 (1838); Marbury v. Madison, 5 U.S. (1 Cranch) 137 (1803). This does not mean, however, that a superior may never exercise any control in regard to ministerial duties; he may still, in many instances, control the way in which the dnty is to be performed, to such extent as is not incompatible with the mandate of the legislature.

137. See, e.g., Waite v. Macy \& Co., 246 U.S. 606 (1918); Bruhl Bros. \& Co. v. Wilson, 123 F. 957 (C.C.R.I. 1903).

138. Thus, in one case, a local postmaster, acting upon an instruction of the Postmaster General, refused to dehver registered letters addressed to the plaintiff. The Post: master General had statutory authority to give such instructions, but only "upon evidence satisfactory to him that any person is engaged in conducting any fraudulent lottery ...." When the court found that the Postmaster General had no such satisfactory evidence, it held his instruction unlawful, and issued an injunction to restrain the local postmaster from acting in obedience to that instruction. New Orleans Nat'1 Bank v. Merchant, 18 F. 841,846 (C.C. La. 1884).

139. See, e.g., Hawley v. Diller, 178 U.S. 476 (1900); United States v. Cobb, 11 F. 76 (C.C. Mass. 1882).

140. Thus it has been held that the power of the Secretary of the Interior to inquire into the extent and validity of a right to public land claimed by a private in- 
the government is to be preserved, a limitation of this kind is obviously necessary. Just when, if at all, a citizen acquires a vested right which may not be disturbed by a superior order, however, is a difficult question; the answer seems to depend on the particular circumstances of each case. ${ }^{141}$

In other cases the lawful exercise of the power of control may be subject to procedural restrictions, for example, a requirement of notice and hearing upon review by the superior, expressly prescribed by the statute conferring the power or by departmental regulations, or imphed from the due process clause of the Constitution. ${ }^{142}$ There is no clear rule as to when notice and hearing are required before a superior may reverse a decision of his subordinate. The answer seems generally to depend in each case upon the nature of the issue and upon the kind of interest which the private individual has acquired by the decison of the subordinate. Thus, where the superior examines the subordinate decision in the light of new evidence which was not available in the original hearing, the private individual will generally be entitled to a hearing and to confrontation of the witnesses. Where, however, the superior only determines whether the subordinate decision conforms with the law or with official policy, and this very question was argued before the subordinate, a hearing is not generally required. Also, if the subordinate lawfully made his decision without any hearing, it seems reasonable that the superior inay similarly inodify or annul that decision without a hearing.

A court may loold unlawful and invalid a superior order made in violation of the legal restrictions imposed upon the control power ${ }^{143}$ and

dividual against the governmeut ceases wheu a pateut has beeu issued by the department and the legal title has passed to the applicant. See, e.g., Ballinger v. Frost, 216 U.S. 240 (1910); United States v. State Investment Co., 264 U.S. 206 (1924). "If the land officers can do this [i.e., set aside a patent and issue a new one to another person] a fcw weeks or a few mouths after the first patent has issued, what limit is there to their power over private rights?' Johnson v. Towsley, 80 U.S. (13 Wall.) 72, 84 (1871). After a patent has issued, it is a matter for the court to inquire into allegations that the patent is defective, as for violation of the law or for another reason. See, e.g., id.

141. Compare the rule coneerning the expiration of the power of an agency to rehear or reconsider its own decision. $2 \mathrm{~K}$. Davis, supra note 53, § 18.09.

142. As the Supreme Court, speaking of the power of the Conimissioner of the General Land Office to review and set aside a decision of the local land officers, has said: "The party who makes proofs, which are accepted by the local land officers, and pays his money for the land, has acquired an interest of which he cannot be arbitrarily dispossessed .... The government holds the legal title in trust for him, and he may uot be dispossessed of his equitable rights without due process of law. Due process in such case implies notice and a hearing. But this does not require that the hearing must be in the courts, or forbid an inquiry and determination in the Land Department." Orchard v. Alexander, 157 U.S. 372, 383 (1895). See also Hawley v. Diller, 178 U.S. 476, 489 (1900); Cameron v. United States, 252 U.S. 450, $460-61$ (1920).

143. However, if the violation is minor, and may not in itself cause injury or in- 
may enjoin the subordimate from carrying out that order. If, however, the order has already been acted upon, and injury amounting to a tort is thereby inflicted upon a member of the public, the court may hold the subordinate liable in damages, and the superior order will not generally serve as a defense. ${ }^{144}$ Although a superior is not ordinarily hable in tort for the acts of his subordinates, a court might hold liable for damages a superior who gave an unlawful order which resulted in a tortious act by his subordinate. ${ }^{145}$

Where the legality of a superior order may reasonably be in doubt, a subordinate officer may find himself on the horns of a dilemma: to obey the order and run the risk of liability for damages if it is ultimately held to be unlawful, or to disobey the order at the risk of disciplinary measures. This dilemma might properly have been avoided by exempting both the subordinate and the superior from personal liability in tort, at least where the order is not patently unlawful, and imposing the hability upon the administrative agency or the government. Even under present law, however, a subordinate who im good faith obeys an unlawful order may receive indemnification from the administrative agency or the government. ${ }^{146}$

\section{G. Judicial Review of Superior Orders}

Superior orders, as well as subordinate decisions made thereunder, are subject to judicial review like other administrative action. ${ }^{147}$ If,

justice, it does not necessarily invalidate the order. See e.g., Gage v. Gunther, 136 Cal. 338, 346-47, 68 P. 710, 713 (1902).

144. See, e.g., Tracy v. Swartwout, 35 U.S. (10 Pet.) 80 (1836); Hendricks v. Gonzalez, 67 F. 351 (2d Cir. 1895); cf. Moore Ice Cream Co. v. Rose, 289 U.S. 373 (1933). This liability, of course, is subject to the immunity generally given to public officers. On this immunity, see F. GooDNow, supra note 7, at 398-408; W. Prosser, HANDBOOK OF THE LAW OF TORTS $\$ 126$ (3d ed. 1964).

145. See, e.g., Rich v. Warren, 123 F.2d 198 (6th Cir. 1941). See also Note, The Tort Liability of Public Officers for the Acts of Their Subordinates, 1961 LAW FoRUM 505.

146. "Some personal inconvenience may be experieuced by au officer who shall be leld respousible in damages for illegal acts done under instructions of a superior; but, as the government in such cases is bound to indemnify the officer, there can be no eventual hardship." Tracy v. Swartwout, 35 U.S. (10 Pet.) 80, 99 (1836). And, according to an opinion of an Attorney General, the expenses incurred by the officer in defending such an action ought to be reimbursed to him. 9 OP. ATr'y GEN. 51 (1857). See also 43 AM. JUR. Public Officers $\S \S 289,520$ (1942).

147. "[A]lthough the collector must carry into effect all instructions of the secretary of the treasury relative to the execution of the revenue laws, yet as to third persons the legality of the collector's action is open to judicial review." United States v. Beebe, 117 F. 670, 680 (C.C. Mass. 1902). See also Greely v. Thompson, 51 U.S. (10 How.) 225, 234 (1850); Barr v. United States, 324 U.S. 83, 94 (1945). As with other administrative acts, the challenged action, whether a superior order or a subordinate decision dictated by a superior order, is not open to review in collateral proceedings, except where it is void for excess of jurisdiction. See, e.g., Knight v. United 
however, the decision of the subordinate may still be appealed to a superior officer or board, a court may refuse review pending exhaustion of this remedy. ${ }^{148}$ After administrative review, judicial review will normally focus on the decision of the superior. However, this may also entail review of the subordinate decision as well, ${ }^{140}$ if, for example, it is alleged that the superior order is invalid by reason of a defect such as the lack of a hearing in the initial subordinate decision. If the proceedings before the superior are found defective, and only the superior decision is held invalid, the subordimate decision may then stand as the final administrative action. ${ }^{150}$ This, however, does not necessarily preclude the superior froin again reviewing and reversing the same subordinate decision if he can avoid the defect which invalidated his first decision.

The fact that the challenged action is taken in obedience to a superior order does not affect the form of judicial review. However, a difficult question arises as to when the superior is an indispensable party to the review proceedings. According to a leading opinion, the superior officer is an indispensable party if the decree granting the rehef sought will require him to take action, either by exercising directly a power lodged in him or by having a subordinate exercise it for him. ${ }^{161}$ The question was of great practical importance when public officers usually had to be sued in the district in which they resided; in the case of superior officers this was often the District of Colunbia. ${ }^{162}$ It is no longer critical, however, as superior officers may now also be sued in the judicial district in which the cause of action arose, or in the district in which any real property involved in the action is situated, or, if no real property is involved in the action, in the district in which the plain-

States Land Ass'n, 142 U.S. 161, $176-77$ (1891); King v. McAndrews, 111 F. 860 (8th Cir. 1901).

148. See, e.g., United States v. Sing Tuck, 194 U.S. 161 (1904); Reconstruetion Finance Corp. v. Lightsey, 185 F.2d 167 (4th Cir. 1950). For a discussion of the doctrine of exhaustion of administrative remedies, see $3 \mathrm{~K}$. Davis, supra note 53, ch. 20. Where, however, the subordinate decision immediately becomes operative, and is not suspended until the administrative appeal is determined, the availability of the appeal will not generally bar judicial review. See Administrative Procedure Aet $\$ 10$ (c), 5 U.S.C. $\$ 704$ (Supp. IV, 1965-68). In such a case the person aggrieved by the decision may choose between administrative and judicial review.

149. "A preliminary, procedural, or intermediate agency action or ruling not directly reviewable is subject to review upon the review of the final agency action." Administrative Procedure Act $\$ 10$ (c), 5 U.S.C. $\$ 704$ (Supp. IV, 1965-68).

150. E.g., Stuart v. Board of Supervisors, 195 Miss. 1, 11 So. 2d 212 (1943).

151. Williams v. Fanning, 332 U.S. 490, 493-94 (1947). For criticism and further details, see $3 \mathrm{~K}$. DAvis, supra uote 53, $\$ 27.08$; Byse, Proposed Reforms in Federal "Nonstatutory" Judicial Review: Sovereign Immunity, Indispensable Parties, Mandamus, 75 HARV. L. REV. 1479 (1962).

152. See Byse, supra note 151. 
tiff resides. ${ }^{153}$ Since there is no longer any practical impediment to suing superior officers, it is advisable to join the superior whenever any doubt exists as to whether or not he is an indispensable party.

While the restrictions upon the power of control, as enforced by way of judicial review, are indeed substantial, the power remains very broad and potent. The courts generally appreciate the need for superior control. Consequently, they have given liberal construction to the many statutes which provide for sucl control. Especially significant is their reluctance to review administrative action which is still subject to review by the superior, or to interfere with the discretion involved in the exercise of the power of control. In sum, statutory provisions prescribing superior control in practice constitute effective devices for securing the coordination and responsibitity whicls are essential to effective public administration. Sucli provisions, lowever, do not in themselves assure the desired ends. Coordination, responsibility, and efficiency are not purely legal matters and are not to be achieved by purely legal ineasures. They depend for their achievement upon proper organization, methods, personal relations, and a liost of other factors. Yet, to the extent that the law may aid in this process, statutory provisions establishing superior control seem inost salutary.

CONTROL THROUGH CONCENTRATION OF POWERS

IN HEADS OF DEPARTMENTS

The system of superior control has continued to exhibit defects, notwithstanding statutory provisions establishing such control. In 1949 the Hoover Commission reported that "The line of command and supervision from the President down through his department heads to every employee, and the line of responsibility from each employee of the executive branch up to the President, has been weakened, or actually broken, in many places and in many ways."154 The report gave the

153. 28 U.S.C. $\S 1391$ (1964).

154. HOOVER COMM'N REPORT, supra note 2, at 5. "That line of responsibility still exists in constitutional theory, but it has been worn away by adininistrative practices, by political pressures, and by detailed statutory provisions. Statutory powers often have been vested in subordinate officers in such a way as to deny authority to the President or a department head. For example, the statute governing the sale of helium to a foreign nation gave the Secretary of the Interior the authority to control such sales regardless of the opinion of the President. The Corps of Engineers of the United States Army, in another case, has the statutory duty of preparing river development plans, and the Secretary of the Army is not responsible for its selection of projects.

"On some occasions the responsibility of an official to his superior is obscured by laws which require him, before acting, to clear his proposals with others. This breaks 
impression that many-far too many-subordinate officers vested with statutory powers are legally exeinpt from superior control. The fact is, however, that statutes conferring power of control upon superiors are widespread, and only a small number of subordinates have escaped the embrace of these provisions. To be sure, a substantial number of department heads are not explicitly placed by statute under the control of the President, but the President's power to reinove lieads of departments at will is generally sufficient to secure compliance with his instructions. Although a head of a departinent might in a rare case defy such an instruction, he might well have done so even if he were subjected to presidential control by statute. Indeed, if the line of command and supervision has been weakened or broken in many places, as the Hoover Commission report states, this is probably owing mainly to extra-legal factors, such as administrative practices and political pressures, ${ }^{155}$ and ought to be countered mainly with extra-legal measures.

Be that as it may, the Commission recommended that the President be given statutory authority to reorganize the executive branch, so as to promote coordination and efficieney. ${ }^{150}$ Congress adopted the recommendation by enacting the Reorganization Act of 1949. ${ }^{167}$ Under this Act the President is authorized to prepare reorganization plans for any administrative agency. ${ }^{158}$ Such a plan may, annong otler things, abolish functions, transfer functions to the jurisdiction and control of another agency, consolidate or coordinate functions within an agency, or authorize an officer to delegate any of his functions. ${ }^{159}$ The plan inust be transmitted to Congress, and it becoines effective after sixty days, unless it is disapproved by a resolution of either House. ${ }^{100}$

Since the passage of this Act, various Presidents liave prepared soine seventy reorganization plans, and most have been put into effect. ${ }^{101}$

the line of responsibility, and encourages indecision, lack of initiative, and irresponsibility." Id. "Any systematic effort to improve the organization and administration of the Government, thercfore, must: . . . . Establish a clear line of control from the President to these department and agency heads and from him to their subordinates with correlative responsibility from these officials to the President, cutting through the barriers which have in many cases made bureaus and agencies partially independent of the Chief Executive." Id. at 7. See also id. at 23, 24.

155. See TASK Force Report, supra note 131, at 35-37, 45-47.

156. For further details, see B. SchwarTZ, AMERICAN CONSTITUTIONAL LAW 120-24 (1955).

157. 5 U.S.C. $\$ \S 901-13$ (Supp. IV, 1965-68). The Act has been extended until April 1, 1971. Pub. L. 91-5, 83 Stat. 6 (1969).

158. Including the independent agencies. See definitions in 5 U.S.C. $\$ \S 105,902$ (Supp. IV, 1965-68). The only exceptions are the General Accounting Office and the Comptroller General of the United States. 5 U.S.C. \$ 902 (Supp. IV, 1965-68).

159. 5 U.S.C. \& 903(a) (Supp. IV, 1965-68).

160. Id. \$§ 903(b), 906(a).

161. Typical provisions of a reorganization plan are the following:

Section 1. Transfer of functions to the Secretary.-(a) Except as otherwise 
These plans have almost effected the complete process of concentration of executive powers which has long been in progress. While conferring many powers on subordinate officers, the Congress has always vested many other powers-in addition to the power of control-in heads of departments. ${ }^{162}$ Virtually all other executive powers, originally vested by statute in subordimate officers and agencies of the various departments, have now been transferred to the department heads. ${ }^{163}$ This

provided in subsection (b) of this section, there are hereby transferred to the Secretary of the Interior all functions of all other officers of the Department of the Interior and all functions of all agencies and employees of such Department.

(b) This section shall not apply to the functions vested by the Administrative Procedure Act (60 Stat. 237) in hearing examiners employed by the Department of the Interior, nor to the functions of the Virgin Islands Corporation or of its board of directors or officers.

Section 2. Performance of functions of Secretary.-The Secretary of the Interior may from time to time make such provisions as he shall deem appropriate authorizing the performance by any other officer, or by any agency or employee, of the Department of the Interior of any function of the Secretary, including any function transferred to the Secretary by the provisions of this reorganization plan.

Reorganization Plan No. 3 of 1950, 64 Stat. 1262. Similar provisions in other reorganization plans apply to almost all other departments.

The reorganization plans also abolished many statutory offices, the functions of which had been transferred to the Secretaries. See, e.g., Reorganization Plan No. 3 of 1949, 63 Stat. 1066. A reorganization plan, however, does not affect powers which have been vested in subordinate officers by legislation enacted subsequent to the date of that plan. See Reorganization Plan No. 3 of 1950, 60 Interior Dec. 448 (1950).

Some reorganization plans apply also to some of the so-called independent regulatory commissions. Their purpose, generally, is to transfer froun the commission to its chairman "[T] executive and administrative functions of the Commission, including functions of the Commission with respect to (1) the appointment and supervision of personnel employed under the Commission, (2) the distribution of business among such personnel and among administrative units of the Commission, and (3) the use and expenditure of funds." And, "The Chairman may from time to time make suclı provisions as he shall deem appropriate authorizing the performance by any officer, employee, or administrative unit under his jurisdiction of any function transferred to the Chairman by the provisions of this reorganization plan." E.g., Reorganization Plan No. 8 of 1950, 64 Stat. 1264 (Federal Trade Commission). Those provisions follow a rccommendation of the Hoover Commission. Hoover COMM'N REPORT, supra note 2, at $431-34$.

162. See TASK Force Report, supra note 131, at 27-29. Thus, for example, "Virtually all of the major agriculture legislation from 1933 to 1948 gave authority specifically to the Secretary to accomplish the desired purposes." Id. at 28 . For conspicuous instances of statutory concentration of powers in heads of departments or agencies, see 22 U.S.C. ch. 38 (Supp. IV, 1965-68) (Departnent of State); 38 U.S.C. cll. 3 (1964) (Veterans' Administration).

163. Recent statutes establishing new departments include provisions similar to those in the reorganization plans. See Department of Housing and Urban Development Act $\S \S$ 5(a), 7(d), 42 U.S.C. $\$ \S ~ 3534,1451$ (Supp. IV, 1965-68); Department of Transportation Act $\S \S 6,9(e), 49$ U.S.C. $\$ 1655,1657$ (e) (Supp. IV, 1965-68). Occasionally a statute may confer powers on the department as a body rather than on the head of the department or a subordinate officer. Such powers would seein to escape the provisions of a reorganization plan transferring to the head of a department all functions 
has substantially affected the pattern of superior control.

Obviously, such concentration of powers calls for a correlative power of delegation. ${ }^{164}$ Specific statutory provisions as well as the reorganization plans have expressly granted heads of departments ample power to delegate their functions. ${ }^{165}$ Furthermore, the department heads may often authorize a function delegated by them to be redelegated. ${ }^{168}$ Thus, a power vested by law in the head may, by successive delegations, reach the bottom of the administrative hierarchy. ${ }^{107}$

of "officers", "agencies", and "employees" of the department. Yet, in many respects, conferring power on a department is equivalent to conferring power on the head of the department. "The Secretary is just as much chargeable with responsibility in conncction with a duty conferred upon the Department of Commerce as in connection with a duty conferred upon the Secretary of Commerce." 39 Op. ATr'y Gen. 541, 543 (1933). In one respect, however, the former duty may be even more commodious for the Secretary than the latter. Where a power is conferred on the Secretary, it may sometimes be doubtful whether he may delegate it or must personally exercise it; but where a power is conferred on the department, it appears that the Secretary is always free to assign it to one of his subordmates. See also 40 Op. ATT'Y GEN. 34, 37-38 (1941).

164. "The formal concept of hierarchy involves the corollary of delegation, by which is meant that basic authority is vested im the individual at the top of the hierarchy but delegated by him to his subordinate leaders. There is an interlocking chain of superior-subordinate relationships from top to bottom. Each subordinate has delegated to him by his immediate superior a sphere of discretion in which he may make decisions, but he is always responsible to his superior for his acts." J. PFIFNER \& R. PRETHUS, supra note 7, at 205.

165. For a typical provision in a reorganization plan, see note 161 supra; for statutory provisions authorizing delegation by heads of departments, inclependent agencies, and subordinate officers see $1 \mathrm{~K}$. Davis, supra note $53 \S 9.02$. For a general provision concerning the authority of heads of agencies to delegate certain powers, sce 5 U.S.C. $\$ 302$ (Supp. IV, 1965-68). Also, some reorganization plans authorize certain regulatory commissions to delegate any of their functions to any member, a hearing examiner, or an employee of the commission. Reorganization Plan No. 3 of 1961, 75 Stat. 837 (Civil Aeronautics Board); Reorganization Plan No. 4 of 1961, 75 Stat. 838 (Federal Trade Commission); Reorganization Plan No. 7 of 1961, 75 Stat. 840 (Federal Maritime Commission). (However, the duty to employ qualified examiners for the couduct of hearings, as prescribed in section 7(a) of the Administrative Procedure Act, is expressly preserved by these plans). The commission retains the right to review the action of any such delegatee upon its own motion or upon petition; but if such review is not sought within the time stated in the rules of the commission, the action of the delegatee then becomes for all purposes the action of the cominission.

Of course, the power of delegation may also be implied from a statute, in the absence of an express provision to that effect. On the power of delegation see generally $1 \mathrm{~K}$. Davis, supra note 53, ch. 9; Grunstein, Subdelegation of Administrative Authority, 13 Geo. Wash. L. REv. 144 (1945).

166. The power to redelegate may be expressly granted by statute. E.g., 5 U.S.C. $\$ 151 \mathrm{c}$ (1964). It may also be granted by implication. See, e.g., Zirin v. McGinnes, 282 F.2d 113 (3d Cir.), cert. denied, 364 U.S. 921 (1960); Shreveport Engraving Co. v. United States, 143 F.2d 222 (5th Cir.), cert. denied, 323 U.S. 749 (1944); United States v. Bareno, 50 F. Supp. 520 (D. Md. 1943).

167. Delegations of power should, generally, be published in the Federal Register. Administrative Procedure Act $\$ 3,5$ U.S.C. $\$ 552$ (Supp. IV, 1965-68). Sce also Kempinski v. Greene, 292 F.2d 820 (3d Cir. 1961). 
A delegation, however, does not generally strip the delegator of his power. He retains a concurrent power and may exercise it as if it were not delegated at all. ${ }^{188}$ As he also remains politically and administratively responsible for the way the power is exercised-in effect, responsible for the acts of the delegatee ${ }^{169}$ - the delegation does not break the line of responsibility. Naturally, then, he should be given, as a corollary of his responsibility, extensive power to control the delegatee. ${ }^{170}$ Indeed, without such control the very purpose of delegation may be defeated. Delegation is meant to assist the delegator in performing his functions, not to divest him of his authority or relieve him of his responsibility. If he were not entitled to control his delegatee, he would be highly reluctant to delegate his power and could not justly be held responsible for the acts of the delegatee. The public interest, too, requires that important decisions-such as estabhishing policy and disposing of novel and difficult cases-should be made, if not by officers at the top of the administrative hierarchy, at least under their direction and supervision. This, mdeed, was one of the main purposes of the Reorganization Act of 1949 and of the subsequent reorganization plans.

The courts appear to appreciate the need and desirability of control by the delgator ${ }^{171}$ - so much so that where a court is disinclined to imply from a statute a power to delegate, it may nevertheless approve a

168. See, e.g., Campbell v. Doe, 54 U.S. (13 How.) 244 (1851); Civil Service Commission v. McDougal, 198 Ark. 388, 129 S.W.2d 589 (1939). In practice, this rule may create a difficult problem of coordination between the delegator and the delegatee.

169. See, e.g., United States v. Bareno, 50 F. Supp. 520, 528 (D. Md. 1943); 39 OP. AtT'y Gen. 541, 546 (1933). See also Barnard, Book Review, 44 AM. Pol. Scr. REv. 990, 1002-03 (1950). Occasionally such responsibility is expressly preserved by statute. See, e.g., Federal Civil Defense Act of 1950 \& 401(g), 50 U.S.C. App. \$ 2253(g) (1964).

170. The need for and methods of control by the delegator were described by the Attorney General's Committee on Administrative Procedure as follows: "Supervision and control by the agency heads should be retained by three methods: (1) stating for the guidance of agency officials those policies which have been crystallized, and which the responsible officers need only apply to the particular case at hand; (2) consideration by the agency heads of cases for which no such policies have been crystallized or in which application of the pohcies is difficult; and (3) requirement that the officers in whom is vested the power . . . submit a periodic report (either weekly or daily) to the agency heads. If these three devices are utilized, the Conumittee believes that the agency heads will be able to guide the important work without devoting unnecessary time and attention to routine matters." REPORT OF THE ATTORNEY General's Comm. on AdMINISTRative Procedure 23 (1941).

171. An analogy may be made between delegation in administrative law and agency in private law. For a case in which extensive use was made of such analogy, see Shreveport Engraving Co. v. United States, 143 F.2d 222 (5th Cir. 1944). It is an established rule in the law of agency that the agent is bound to obey the instructions of the principal. See, e.g., W. SEAVEY, LAW OF AGENCY $\$ 145$ (1964). 
delegation if the delegator has in fact retained substantial control over the delegatee. ${ }^{172}$ There appears to be little authority, lowever, defining the nature and extent of control by the delegator over the delegatee. This is surprising in view of the fact that the bulk of administrative powers is exercised by delegatees and subdelegatees. The dearth of authority allows only an incoinplete outline of the delegator's power of control.

In the first place, the delegator may at any time revoke the delegation. This power in itself, like the power to discharge a subordinate, may induce a delegatee to obey the instructions of his delegator. Further, authority may be delegated partially ${ }^{173}$ or subject to express reservations. ${ }^{174}$ The delegator may exclude froin the delegation certain matters, or lie may provide that, in specific cases or in novel and important problems, the delegatee will only make the initial decisions, and then submit thein for approval. Similarly, he may prescribe that the decisions of the delegatee shall be final except in certain cases which inay or sliould be referred for his review, or he may instruct the delegatee as to the course of action to be taken in specified routine inatters. Also, even where a delegation is on its face complete and unqualified, the delegator retains power of control over his delegatee. In general, this power allows him to give detailed instructions about the exercise of the delegated power: ${ }^{175}$ to interfere in a case pending before the delegatee either by ordering the case transferred to him or by dictating the decision; ${ }^{176}$ to provide for a riglt of appeal from the de-

172. In such a case the court, refusing to label it as a delegation, may regard the act as one done by the superior himself through, or with the aid of, his assistants. Sec, e.g., Shreveport Engraving Co. v. United States, 143 F.2d 222, 227 (5th Cir.), cert. denied, 323 U.S. 749 (1944). See also 39 OP. ATT'Y GEN. 541, 546 (1933).

173. "[I]t must be understood that delegation may be a inatter of degree. It is not true that authority must be dclegated completely or not at all." REPORT OF THE AtTORNEY General's Comm. ON Administrative Proceddre 22 (1941). See, e.g., NLRB v. Duval Jewelry Co., 357 U.S. 1 (1958). See also Cudahy Packing Co. v. Holland, 315 U.S. 357, 368-69 (1942) (Douglas, J. dissenting).

174. See $1 \mathrm{~K}$. Davis, supra note 53, at 616-17. For an exainple of such a delegation, see United States ex rel. Accardi v. Shaughnessy, 347 U.S. 260, 266 (1954).

175. The National Prohibition Act of 1919, 41 Stat. 305, committed its administration to the Commissioner of Internal Revenue, and declared that "Any act authorized to be done by him may be performed by any assistant or agent designated by [him] for that purpose." Id. at 307. The Commissioner of Internal Revenue dclegated his power to issue liquor permits to a prohibition commissioner and local prohibition directors. In Gnerich v. Rutter, 265 U.S. 388, 391 (1924), the Court said: "The act and the regulations make it plain that the prohibition commissioner and the prohibition director are mere agents and subordinates of the Commissioner of Internal Revenue. They act under his direction and perform such acts only as he commits to them by the regulations. They are responsible to him and must abide by his direction. What they do is as if done by him." See also Parish v. United States, 100 U.S. 500, 505 (1879).

176. This would seem to follow logically from the rule that the delegator retains a 
cision of the delegatee; ${ }^{177}$ or to review the decision on his own motion. ${ }^{178}$

In sum, the control exerted by a delegator over his delegatee is generally not less extensive than that exerted by a superior who is by statute charged with the direction and supervision of powers conferred by law on his subordinate. ${ }^{179}$ This is only reasonable in view of the fact that the delegator retains both the delegated power and the responsibility for its exercise. As a matter of reason, unsupported as yet by any authority, it may well be that the delegator is entitled to even more extensive control.

It is clear, however, that in some respects the Reorganization Act of 1949 and the subsequent reorganization plans have actually enhanced the control by heads of departments. First, since the Reorganization Act covers virtually the entire executive branch, it has enabled the President to transer to department heads functions which had been largely outside their control. The wholesale transfer of functions from subordinate officers and agencies to the heads of departments has, it may be assumed, encompassed officers and agencies which, accidentally or intentionally, had not previously come under any of the statutory provisions granting power of control to heads of departments. Also, the President may now, unless Congress disapproves, subject the imdependent regulatory commissions, or any part of their functions, to the control of heads of departments. ${ }^{180}$ Second, when power is concen-

concurrent power. See note 168 supra. But see United States ex rel. Accardi v. Shaughnessy, 347 U.S. 260 (1954). There it was held that the Attorney General was not entitled to dictate the decision of his delegatees, the Board of Immigration Appeals. However, the function of the Board is, seemingly, quasi-judicial; the decision in Accardi may, accordingly, be linited to functions of this nature.

177. See Jay v. Boyd, 351 U.S. 345 (1956). The Attorney General was authorized by statute to suspend deportation of deportable aliens. He delegated this authority to special inquiry officers, and provided for final review by the Board of Immigration Appeals. The Suprene Court approved the delegation. 351 U.S. at 350 n.7, 351 n.8. A fortiori, the delegator may himself hear appeals from the decisions of the delegatee.

178. See Morgan v. Hines, 113 F.2d 849, 850 (D.C. Cir. 1940). One important exception to the delegator's power of control concerns hearing examiners under the Administrative Procedure Act. In sone respects the examiners are subject to superior control. See generally 2 K. DAvis, supra note 53, ch. 10 . However, they are not subject to superior orders as to the substance of the decisions to be made by them in any particular case.

179. In sone cases express provisions in statutes and reorganization plans have made this clear. For example, Reorganization Plan No. 2 of 1949, $\$ 1,63$ Stat. 1065, states: "The functions transferred by the provisions of this section shall be performed by the Secretary of Labor or, subject to his direction and control, by such officers, agencies, and employees of the Departinent of Labor as he shall designate." But a delegator would seem to have just as much control in the absence of such a clause.

180. Thus, one reorganization plan abolished the Maritime Commission-one of the independent regulatory commissions-and transferred its functions partly to the Secretary of Commerce and partly to the Federal Maritime Board-a new agency within the Department of Commerce-which in regard to some of its functions was 
trated in the head of a department and is to be delegated by him, he may freely choose as delegatee the person he considers to be best qualified for the particular function, or the person he trusts to perform the function faithfully according to his policies and instructions. Third, and of great practical importance, it is much easier to revoke a delegation if the delegatee proves to be inefficient or disobedient than it is to discharge an officer. Last, a delegatee who has been chosen and given his function by the head of the department and who knows that the function and responsibility are still retained by the head and that his function may any time be taken away from him may be more inclined to comply with the instructions of the department head than a subordinate officer who has been given his function directly by statute. ${ }^{181}$ The power of the President to control the department heads and, through them, their subordinates, has also been enhanced by the Reorgamization Act, inasmuch as he may now, with congressional approval, transfer functions froin one department head, or froin one agency, to another, or even to himself. ${ }^{182}$

\section{CONCLUSION}

Generally speaking, the law concerning superior control is satisfactory. Reorganization plans have transferred virtually all executive powers, originally vested by statute in numerous subordinates, to the Secretaries. Most of those powers have subsequently been delegated and redelegated. The delegator, however, retains control over the exercise of the power. In many cases, statutory provisions expressly subjecting subordinates to the control of their superiors reinforce this control. To secure control, superiors may generally resort to disciplinary measures, notably the removal of a disobedient official. The courts, on their part, have given a hiberal construction to control provisions, entitling the superior to instruct his subordinates as to the course of action to be taken in a class of cases or in a specific case, and to review, amend or annul the decisions made by his subordinates. In inost cases, therefore, superior control, as prescribed by law, is broad and flexible enough to satisfy all reasonable needs.

In soine cases, however, superior control is defective. A statute,

made independent of the Secretary, and in regard to its other functions remained subject to the general policies of the Secretary. Reorganization Plan No. 21 of 1950, 64 Stat. 1273. However, a later reorganization plan abolished the Federal Maritime Board, and transferred its functions partly to the Secretary of Commerce and partly to the re-established Maritime Commission, which "shall not be a part of any executive department or under the authority of the head of any executive department." Reorganization Plan No. 7 of 1961, 75 Stat. 840.

181. See Barnard, Book Review, 44 AM. Pol. Scr. Rev. 990, 993 (1950).

182. For a plan transferring functions to the President, see Reorganization Plan No. 4 of 1965,79 Stat. 1321. 
for example, which while subjecting a subordinate to the control of his superior gives him a fixed tenure and provides that he shall be removable only for cause or upon reasons to be communicated to the Senate, ${ }^{183}$ may well impair the effectiveness of superior control. Also, where a subordinate is entrusted by statute with powers, yet is not expressly placed under superior control, he is not, under the decision in Kendall v. United States ex rel. Stokes, ${ }^{184}$ subject to direction or supervision by his superior. This decision, reflecting the hostility of early days to centralized government, is based on the presumption that Congress intended the recipient of a power to exercise it independently. Today this presumption appears unsound. There is generally nothing to support it in legislative language or history, and it may not be easily reconciled with the constitutional provisions vesting the President with the executive power and with the duty to take care that the laws be faithfully executed. It nay badly impair effective and just administration, and is contrary to the basic principle that a superior who will and should be held accountable for the mistakes of his subordinate ought to have authority to prevent or rectify such mistakes. It is also unreahistic, since a superior will usually have sufficient means at his disposal to induce his subordinate to be cooperative and obedient. In practice, because the Kendall decision is of very limited application, and virtually forgotten, it is not a serious impediment to superior control. Nevertheless, until expressly overruled, it may still prove harmful on occasion.

It hardly need be emphasized once more that the success of the systein of superior control does not depend solely-or even principally -upon rules of law. The effectiveness of such rules may be impaired as well as enhanced by extra-legal factors. Thus, irrespective of statutory provisions, political pressures or bad personal relations within an administrative unit may impair, sometimes even paralyze, superior control. On the other hand, political loyalty, hope of advancement or other reward, identification with the goals of the superior and inclination to avoid responsibility may secure obedience more effectively than statutory provisions or even the threat of removal. ${ }^{185}$

183. See, e.g., 12 U.S.C. $\S \S 1,2$ (1964) (Comptroller of the Currency).

184. 37 U.S. (12 Pet.) 524 (1838). See note 34 supra.

185. This article has considered the general framework of superior contol in the administrative process. It has not focused attention on those exceptional situations where such control is wholly or partially undesirable. Sometimes Congress expressly exempts a specific official from superior control. In other cases, notably in respect of quasi-judicial functions, this is inferred by the courts. However, the nature aud extent of these exceptions deserve a separate discussion and will be the subject of a future article. 


\title{
California Law Review
}

\begin{tabular}{lll}
\hline \hline VoL. 57 & OCTOBER 1969 & No. 44 \\
\hline \hline
\end{tabular}

\section{BOARD OF EDITORS}

\author{
Editor-in-Chief \\ H. LEE VAN BOVEN \\ Managing \\ THORNTON E. RoBIson
}

WALTER L. CarpenetI

A. TERRY SLOCUM

Notes \& Comments

Articles

Derer A. WesteN

Research

Peter N. Stmon

JAMES W. BROWN

MARY LU EVERETT

LESLIE S. KIINGER

Marietta Poerio

Eric R. Roost

WENDY WILLIAMS

Executive Editor

JEFFREY R. FREUND

GIeNN C. Frese

VINCENT L. RICCI

Book Reviews

ROBERT G. WERNER

PAUL Hoeber

DAVID J. COOPER

Ned A. Fine

JOHN GRATWER

ROBERT W. JINKS

LEONARD MENTZER

TMOTHY TOWER

Special Projects

FrankLIN R. Garfield

KOREY A. MANDEL

Frank D. BeRRY

William BILlingslea, JR.

MERRICK John BobB

J. Michael BRENNAN

William M. Chamberlain

WiLliam Frederick CoOK

G. KIP EDWARDS

STEVEN Finell

\begin{abstract}
ELLyn A. Hershman
GREGORY J. HOBBS, Jr.

Charles H. Hurd

JOSEPH T. KIEFER

JEFF KINGSTON

DARVISH M. KORDESTANI

MrChaEL GEORge KozAK

Douglas M. Laurice
\end{abstract}
Administrative Aide
SUSAN G. VEGA

\author{
RICHARD FRASER LYON \\ RoBIN MEADOW \\ Michael L. MEYeRs \\ Douglas Alan Ogzesby \\ Richard L. PEREZ \\ Bruce S. Ross \\ DOUGLAS SYKES \\ MaRia TANKENSON
}

